\title{
Characterizing the impact of urban emissions on regional aerosol particles: airborne measurements during the MEGAPOLI experiment
}

\author{
E. J. Freney ${ }^{1}$, K. Sellegri ${ }^{1}$, F. Canonaco ${ }^{2}$, A. Colomb ${ }^{1}$, A. Borbon ${ }^{3}$, V. Michoud ${ }^{3}$, J.-F. Doussin ${ }^{3}$, S. Crumeyrolle ${ }^{1,{ }^{*}}$, \\ N. Amarouche ${ }^{4}$, J.-M. Pichon ${ }^{1}$, T. Bourianne ${ }^{5}$, L. Gomes ${ }^{5}$, A. S. H. Prevot ${ }^{2}$, M. Beekmann ${ }^{3}$, and A. Schwarzenböeck ${ }^{1}$ \\ ${ }^{1}$ Laboratoire de Météorologie Physique, CNRS-Université Blaise Pascal, UMR6016, 63117, Clermont Ferrand, France \\ ${ }^{2}$ Paul Scherrer Institute, Laboratory of Atmospheric Chemistry, 5232 Villigen PSI, Switzerland \\ ${ }^{3}$ Laboratoire Interuniversitaire des Systèmes Atmosphériques, LISA/IPSL, UMR CNRS 7583, Université Paris Est Creteil \\ (UPEC) and Universite Paris Diderot (UPD), France \\ ${ }^{4}$ CNRS, Div Tech, Inst Natl Sci Univers, UPS 855, 92195 Meudon, France \\ ${ }^{5}$ Centre National de Recherches Météorologiques, Météo-France, Toulouse, URA1357, France \\ *now at: Laboratoire d'Optique Atmosphérique (LOA), UMR8518, CNRS - Université Lille 1, Villeneuve d'Ascq, France
}

Correspondence to: E. J. Freney (e.freney@opgc.univ-bpclermont.fr)

Received: 11 July 2013 - Published in Atmos. Chem. Phys. Discuss.: 24 September 2013

Revised: 7 December 2013 - Accepted: 21 December 2013 - Published: 6 February 2014

\begin{abstract}
The MEGAPOLI (Megacities: Emissions, urban, regional and Global Atmospheric POLlution and climate effects, and Integrated tools for assessment and mitigation) experiment took place in July 2009. The aim of this campaign was to study the aging and reactions of aerosol and gas-phase emissions in the city of Paris. Three ground-based measurement sites and several mobile platforms including instrument equipped vehicles and the ATR-42 aircraft were involved. We present here the variations in particle- and gas-phase species over the city of Paris, using a combination of high-time resolution measurements aboard the ATR-42 aircraft. Particle chemical composition was measured using a compact timeof-flight aerosol mass spectrometer (C-ToF-AMS), giving detailed information on the non-refractory submicron aerosol species. The mass concentration of black carbon (BC), measured by a particle absorption soot photometer (PSAP), was used as a marker to identify the urban pollution plume boundaries. Aerosol mass concentrations and composition were affected by air-mass history, with air masses that spent longest time over land having highest fractions of organic aerosol and higher total mass concentrations. The Paris plume is mainly composed of organic aerosol (OA), BC, and nitrate aerosol, as well as high concentrations of anthropogenic gasphase species such as toluene, benzene, and $\mathrm{NO}_{\mathrm{x}}$. Using $\mathrm{BC}$
\end{abstract}

and $\mathrm{CO}$ as tracers for air-mass dilution, we observe the ratio of $\triangle \mathrm{OA} / \triangle \mathrm{BC}$ and $\triangle \mathrm{OA} / \triangle \mathrm{CO}$ increase with increasing photochemical age $\left(-\log \left(\mathrm{NO}_{\mathrm{x}} / \mathrm{NO}_{\mathrm{y}}\right)\right)$. Plotting the equivalent ratios of different organic aerosol species (LV-OOA, SV$\mathrm{OOA}$, and HOA) illustrate that the increase in $\mathrm{OA}$ is a result of secondary organic aerosol (SOA) formation. Within Paris the changes in the $\triangle \mathrm{OA} / \triangle \mathrm{CO}$ are similar to those observed during other studies in London, Mexico City, and in New England, USA. Using the measured SOA volatile organic compounds (VOCs) species together with organic aerosol formation yields, we were able to predict $\sim 50 \%$ of the measured organics. These airborne measurements during the MEGAPOLI experiment show that urban emissions contribute to the formation of OA and have an impact on aerosol composition on a regional scale.

\section{Introduction}

It is necessary to characterize pollution arising from anthropogenic activities in large urban areas in order to understand its effects on health, as well as its influence on regional and global scale atmospheric chemistry and radiative forcing. Several studies have monitored the outflow from large cities 
and the evolution of aerosol chemical and physical properties as they are emitted from their source and diluted into regional air masses. Some of these studies include MILAGRO (Mexico City emissions, DeCarlo et al., 2008), SOAR-1 (southern California, Docherty et al., 2011), and the EM25 campaign in London, UK (McMeeking et al., 2012). Each of these studies included a combination of several measurement sites situated at different distances from the centre of the city as well as mobile (airborne or vehicle) measurement platforms. Mobile measurement platforms provide a unique insight into the changes in the chemical and physical properties over both horizontal and vertical scales.

Results arising from these studies show large variations in particle composition as air masses move away from the city centre and are mixed with background air. In general, high concentrations of organic and nitrate aerosol particles are measured within the centre of the plume and sulfate concentrations increase further from the city when the urban plume mixes with regional air masses (DeCarlo et al., 2008). The majority of these studies also show that there are rapid increases in the formation of secondary organic aerosol (SOA) as the air mass leaves the urban area (Volkamer et al., 2006; Kleinman et al., 2008; DeCarlo et al., 2010). Although recent studies show that it is possible to theoretically predict the mass concentration and temporal evolution of SOA measured in the atmosphere (Hodzic et al., 2010), there is still a high degree of uncertainty in understanding SOA formation mechanisms. Field measurements in different geographical areas are essential to improve our understanding of how aerosol particles are formed and processed in the atmosphere.

With a population of about 11.6 million inhabitants (about $20 \%$ of the French population), greater Paris (France) is among the most populated megacities in Europe. Due to its favourable geographical situation (far from other big European cities and influenced very often by clean oceanic air masses), it is a good candidate for investigating the build-up of the urban contribution to the regional air pollution burden. In recent years, there have been increases in air quality studies within the Paris region using both measurement and modelling tools (Sciare et al., 2010; Hodzic et al., 2005; Zhang et al., 2013). Important conclusions of these studies include the need for size-resolved composition measurements of $\mathrm{PM}_{2.5}$ aerosol, as well as the need for vertical measurements of aerosol species. Particulate mass of fine aerosols has been continuously monitored at several sites within greater Paris for almost $8 \mathrm{yr}$ by the local air quality network (AIRPARIF). However, dedicated measurements of aerosol composition in the urban plume have never been performed.

The FP7/MEGAPOLI project (Megacities: Emissions, urban, regional and Global Atmospheric POLlution and climate effects, and Integrated tools for assessment and mitigation, 2008 to 2011) is aimed at improving the understanding of the impact of megacities on air quality on a local, regional, and global scale (Baklonov et al., 2010). It additionally aims to improve our understanding of the relationships existing between air quality and climatic change on both a local and regional scale. As part of this project, two large field experiments were realised in the greater Paris region in summer 2009 and winter 2010. Freutel et al. (2013), Crippa et al. (2013a) and Healy et al. (2012) described the chemical composition of aerosol particles measured at the groundbased sites during the summer and winter campaigns, respectively. Here we discuss airborne measurements of the main chemical constituents of $\mathrm{PM}_{1}$ within the city plume. Local and regional contributions to the major chemical constituents of $\mathrm{PM}_{1}$ are discussed together with back trajectory air-mass analysis and are compared with variations in the concentration of volatile organic compounds (VOC) and other gasphase species.

\section{Materials and methods}

\section{$2.1 \quad$ ATR-42 aircraft}

All measurements were performed aboard the ATR-42, a French national research aircraft run by SAFIRE (French aircraft service for environmental research). The ATR-42 was equipped to perform measurements of particles and gasphase species as well as cloud droplet size distribution. The different meteorological variables measured included temperature, dew point temperature, pressure, turbulence, relative humidity, wind speed, and direction. Aerosol particle species were sampled through a forward-facing inlet installed in place of a side window of the aircraft. This was an isokinetic and isoaxial inlet with a $50 \%$ sampling efficiency for particles with a diameter of $4.5 \mu \mathrm{m}$. The inlet was composed of an outer sleeve for channelling air and a tube radius of curvature high enough to limit losses during transport of particles (Crumeyrolle et al., 2008). Before aerosol particles were sampled by the compact time-of-flight aerosol mass spectrometer (C-ToF-AMS), they passed through a pressure controlled inlet (PCI). The PCI ensured a constant pressure at the inlet of the C-ToF-AMS ( $\sim 400 \mathrm{hPa})$, avoiding pressure changes to the aerodynamic inlet of the C-ToF-AMS during airborne sampling (Bahreini et al., 2008). The aerodynamic lens of the C-ToF-AMS is reported to have a $100 \%$ transmission efficiency between $80 \mathrm{~nm}$ and $500 \mathrm{~nm}$ when using a $100 \mu \mathrm{m}$ orifice at $1016 \mathrm{mBarr}$ (Liu et al., 2007). Bahreini et al. (2008) illustrated when using a PCI between $\sim 400$ and $654 \mathrm{hPa}$ mbarr (assuming that ambient pressure is greater than that of the PCI) with an orifice $>100 \mu \mathrm{m}$ that the transmission efficiency of the lens is not changed. Bahreini et al. (2008) tried a number of different critical orifices ranging from $120 \mu \mathrm{m}$ up to $180 \mu \mathrm{m}$; an orifice of $130 \mu \mathrm{m}$ diameter was used in this study. Data acquired from the C-ToF-AMS as well as all other measurements aboard are corrected to temperature $\left(\sim 22^{\circ} \mathrm{C}\right)$ and pressure $(950 \mathrm{hPa})$ of the plane.

For black carbon (BC) measurements, a particle soot absorption photometer (Radiance research ${ }^{\circledR}$ (PSAP) measured 
the particle absorption coefficient. The sampling flow rate of the PSAP was $\sim 1.2 \mathrm{~L} \mathrm{~min}^{-1}$. Instrument time resolution of the PSAP was $<10 \mathrm{~s}$. Light absorption coefficient was corrected according to the Bond et al. (1999) method. Filters were changed prior to each flight to ensure that transmission efficiency was greater than $80 \%$. Black carbon concentration were calculated using the light absorption coefficient at $650 \mathrm{~nm}$ and a mass specific absorption coefficient of $Q_{\mathrm{BC}}=6.6 \mathrm{~m}^{2} \mathrm{~g}^{-1}$. This calculation was done in accordance with conclusions from a workshop (EUSAAR 2007) on the comparison of different measurements of absorption coefficient, and with the assumption that $\mathrm{BC}$ always interacts the same way with light whatever the BC particle's size. It has been illustrated in several studies that the majority of BC mass is measured in the submicron size mode (Sellegri et al., 2003).

A scanning mobility particle sizer (SMPS) measured the mobility diameter of aerosol particles from 30 to $500 \mathrm{~nm}$ with a resolution of $84 \mathrm{~s}$. The total number concentration measured by the SMPS was compared with that of the CPC to ensure that the two instruments were coherent for comparison with the C-ToF-AMS.

There was no impactor placed upstream of the PSAP, CPC or C-ToF-AMS; however, given the length of tubing and the presence of several bends in the sampling line, the $50 \%$ sampling efficiency for aerosol particles was calculated to be approximately $2.5 \mu \mathrm{m}$ (McFarland et al., 1997).

\subsection{Back trajectory analysis}

In order to determine the transport pathways of the aerosol particles prior to arriving along the flight track $(700 \mathrm{~m})$, the HYbrid Single-Particle Lagrangian Integrated Trajectory (HYSPLIT) model was used (Draxler and Hess, 1998; Draxler and Rolph, 2013). Air mass backward trajectories were calculated for the arrival pressure level of $950 \mathrm{hPa}$ and were calculated every six hours, the first starting at 00:00 UTC time. Air masses were followed $72 \mathrm{~h}$ backwards in one-hour time steps. Figure 1 shows examples of trajectories calculated for four flights. The map of Europe is separated into grid squares with a $0.5^{\circ}$ resolution. Each grid square is coloured by the amount of time that the air mass spent in that area.

\subsection{Aerosol chemistry measurements}

The chemical composition and mass concentration of the non-refractory submicron particulate matter $\left(\mathrm{NR}-\mathrm{PM}_{1}\right)$ was measured with an Aerodyne C-ToF-AMS with a time resolution of $36 \mathrm{~s}$ (Drewnick et al., 2005; Canagaratna et al., 2007). In order to extract chemically resolved mass concentrations of individual species, the C-ToF-AMS raw data were evaluated using the standard fragmentation table (Allan et al., 2004). Adjustments to the fragmentation table were made based on particle-free measurement periods that were per- formed during each flight. The resolved mass concentrations included nitrate $\left(\mathrm{NO}_{3}\right)$, sulfate $\left(\mathrm{SO}_{4}\right)$, ammonium $\left(\mathrm{NH}_{4}\right)$, organics (Org), and chloride (Chl) species. Ionization efficiency (IE) calibrations, using ammonium nitrate, were made after each research flight, giving IE values of $2.0 \pm 0.5 \times 10^{-7}$ for nitrate.

The calculation of quantitative mass concentrations from the C-ToF-AMS mass spectra requires that a collection efficiency (CE) be applied to the data. The CE is defined as the fraction of the particle mass that is measured by the $\mathrm{C}$ ToF-AMS, relative to what would have been measured if all particles were spherical and particle bounce was negligible. Recently it has been demonstrated that particles containing high ammonium nitrate concentrations are more efficiently sampled by the C-ToF-AMS than other inorganic and organic species (Middlebrook et al., 2011). It is therefore recommended that a composition-dependent $\mathrm{CE}$ be applied to the data (Eq. 1):

$\mathrm{CE}_{\text {dry }}=\max (0.5,0.264+0.943 \times \mathrm{ANMF})$,

in which a constant $\mathrm{CE}$ of 0.5 is used for ammonium nitrate mass fraction (ANMF) $\leq 0.25$ and a linear CE increase up to 1 for ANMF $>0.25$ (Freney et al., 2011) $(\mathrm{CE}=1$ for $\mathrm{ANMF}=1$ ). A CE for aerosol acidity is not included in this study since the ratio of the $\mathrm{NH}_{4}$ measured ( $\left.\mathrm{NH}_{4 M E A S}\right)$ by the C-ToF-AMS to the $\mathrm{NH}_{4}$ predicted $\left(\mathrm{NH}_{4 \mathrm{PRED}}\right.$ ) (the amount of $\mathrm{NH}_{4}$ necessary to neutralize the measured $\mathrm{SO}_{4}$, $\mathrm{NO}_{3}$, and $\mathrm{Chl}$ ) was always between 0.77 and 0.82 . In Middlebrook et al. (2012), a CE for aerosol acidity was included only when the ratio of $\mathrm{NH}_{4 \text { MEAS }} / \mathrm{NH}_{4 \text { PRED }}$ was $<0.73$. In order to validate our chosen $\mathrm{CE}$, we compared the total mass concentrations of aerosol particles sampled by the C-ToFAMS and BC with that sampled by a scanning mobility particle sizer (SMPS). The SMPS number concentrations were converted to mass concentrations using an average density of $1.8 \mathrm{~g} \mathrm{~cm}^{-3}$ for all aerosol particles. Comparing the total mass concentration measured by the C-ToF-AMS and BC for all research flights with the corresponding SMPS measurements, we obtain a correlation with an average $\mathrm{r}^{2}$ and slope of $0.78 \pm 0.13$ and $0.71 \pm 0.15$, respectively (Fig. S1).

\subsubsection{PMF analysis}

Positive matrix factorization (PMF) (Paatero and Tapper, 1994; Paatero, 1997) was performed with the PMF2 software package (P. Paatero, University of Helsinki, Finland) and the PMF analysis and evaluation tool (Ulbrich et al., 2009). PMF is a statistical technique which separates the ensemble organic mass spectral time series $(\mathbf{X})$ into a linear combination of a set of factor profiles $(F)$ and their time-dependant intensities $(G)$ (Paatero and Tapper, 1994; Paatero, 1997). PMF is therefore described by the matrix equation $\mathbf{X}=G F+\mathbf{E}$, where $\mathbf{E}$ is the residual matrix and is defined as the difference between the data matrix and the fitted solution (introduced by Lanz et al., 2007 for AMS (aerosol mass spectra) data). Each 
of these classes of mass spectra generally represents different sources of organic aerosols. The error matrix calculated using the Squirrel software (version 1.51) was adjusted following the recommendations of Paatero and Hopke (2003). A minimum error of 1 ion was applied throughout the $\mathbf{X}$ matrix, and the organic peaks calculated as the fraction of the $\mathrm{CO}_{2}^{+}$ion $(\mathrm{m} / z 44,18,17$, and 16$)$ were down-weighted, as described in Ulbrich et al. (2009). In addition, several $\mathrm{m} / z$ values were removed due to either low $(\mathrm{m} / \mathrm{z} 19$ and 20$)$ or high $(\mathrm{m} / \mathrm{z}$ 29) signal. The number of PMF factors was determined by analysing the correlations of the temporal variations of each resolved organic species with external tracers (including $\mathrm{CO}$, $\mathrm{O}_{3}, \mathrm{NO}_{\mathrm{x}}, \mathrm{SO}_{2}, \mathrm{NO}_{3}^{-}$, and $\mathrm{SO}_{4}^{2-}$ ) and with reference mass spectra. Reference mass spectra were taken from the AMS database (http://cires.colorado.edu/jimenez-group/AMSsd/).

\subsection{Determination of plume boundaries and background values}

Black carbon (BC) concentrations are used to define the plume boundaries during each research flight (RF) (Figs. 2a and S3a). The background value of $\mathrm{BC}$ was determined from the lowest values of $\mathrm{Org} / \mathrm{BC}$ ratio $\left(\sim 0.5 \mu \mathrm{g} \mathrm{m}^{-3}\right.$ in Fig. S4c). The background $\mathrm{BC}$ mass concentration ranged from 0.1 to $0.6 \mu \mathrm{g} \mathrm{m}^{-3}$. This value was then confirmed based on up-wind BC mass concentrations (Fig. S4a). Plume boundaries were defined as when the difference in $\mathrm{BC}$ above background $(\triangle \mathrm{BC})$ was $\geq 0.15 \mu \mathrm{g} \mathrm{m}^{-3}$. However, since background mass concentrations of $\mathrm{BC}$ varied between flights, each flight was classified independently. For all RF, the $\triangle \mathrm{BC}$ within the urban plume was observed to vary from 0.15 to $0.58 \mu \mathrm{g} \mathrm{m}^{-3}$, with lowest values measured during eastern flights and highest during northern flights.

Similar procedures were performed for organic aerosols (OA) and CO concentrations. Care needs to be taken in defining the background values in order to calculate accurate values of $\triangle \mathrm{OA} / \triangle \mathrm{CO}$ or $\triangle \mathrm{OA} / \triangle \mathrm{BC}$ (Sect. 3.3.2). Subtracting incorrect background values can skew these ratios to either very large or very small values.

\subsection{Gas-phase measurements}

$\mathrm{CO}$ and $\mathrm{O}_{3}$ were sampled through a rear-facing $1 / 4$ inch Teflon tube and were measured using infra-red and ultraviolet analysers (Thermal-environmental instruments), respectively (Nedelec et al., 2003). $\mathrm{NO}$ and $\mathrm{NO}_{2}$ were sampled through a separate rear-facing pressure controlled inlet at a $30 \mathrm{~s}$ time resolution and measured using the MONA (Measurement of Nitrogen on Aircraft) instrument based on ozone chemiluminescence and developed by the Laboratoire Interuniversitaire des Systèmes Atmosphériques (LISA), Paris. $\mathrm{NO}_{\mathrm{y}}$ measurements were performed using a separate heated $\left(60^{\circ} \mathrm{C}\right)$ sampling line to avoid any loss of nitric acid. The air then passed through a gold converter $(8 \mathrm{~mm}$ gold-coated inox tube) heated to $200^{\circ} \mathrm{C}$ with $\mathrm{H}_{2}$ as a reagent to convert nitrogen species into NO. Additional details of the MONA instrument are supplied in the Supplement.

A high sensitivity proton-transfer-reaction mass spectrometer (PTR-MS) from Ionicon Analytik (Innsbruck, Austria), providing measurements on the volatile organic carbon (VOC) in the atmosphere, was redesigned to fit in an ATR-42 rack to meet aircraft safety rules. This was the first deployment of the instrument on board the ATR-42. Typical background counts for aromatics were between 0.8 and 10 counts $^{-1}$. Detection limits, defined as the $1 \sigma$ variability in the background mixing ratios, were between $0.070 \mathrm{ppb}$ and $0.150 \mathrm{ppb}$ for a $2 \mathrm{~s}$ dwell time. A scheme of the PTR-MS configuration and operating conditions, including calibration protocols on board, are provided in Borbon et al. (2013).

\section{Results and discussion}

A total of 8 research flights (RFs) with reliable C-ToF-AMS measurements were available aboard the ATR- 42 from 13 to 29 July 2009 as part of the MEGAPOLI experiment. The flight trajectory consisted of a loop around the Paris metropolis area and then a series of horizontal transects over the plume for a distance up to $200 \mathrm{~km}$ and at altitudes less than $700 \mathrm{~m}$ above sea level. RFs were carried out in the northern, northeastern, and eastern direction from the centre of Paris, depending on the wind directions. The aim of this flight plan was to measure the urban plume at several distances and at an increasing oxidation time as it was leaving the Paris metropolitan area. PTR-MS data were available for a total of four flights and $\mathrm{NO}_{\mathrm{x}} / \mathrm{NO}_{\mathrm{y}}$ measurements were available for five RFs. A list of all measurements aboard the ATR-42 for each research flight is presented in Table S1.

In Freutel et al. (2013), air masses were classified into three categories: Central Europe, Atlantic polluted, and Atlantic clean. In this work, research flights only took place during "Atlantic polluted" or "Atlantic clean" periods. Atlantic polluted were generally classified as air masses that had spent more time over land and correspond to flights N16, $\mathrm{N} 21$, and $\mathrm{N} 29$. Average temperature measured on the ground during these meteorological events were $22^{\circ} \mathrm{C} \pm 4{ }^{\circ} \mathrm{C}$ for Atlantic polluted and $18{ }^{\circ} \mathrm{C} \pm 3^{\circ} \mathrm{C}$ for Atlantic clean. Similar differences in ambient temperatures were measured aboard the aircraft with $21^{\circ} \mathrm{C} \pm 0.89^{\circ} \mathrm{C}$ for northern sector flights (Atlantic polluted) and $17^{\circ} \mathrm{C} \pm 0.5^{\circ} \mathrm{C}$ for eastern sector flights (Atlantic clean).

\subsection{General results for particle- and gas-phase compositions}

Measurements of gas-phase species showed sharp increases in $\mathrm{NO}$ and $\mathrm{NO}_{2}$ concentrations within the plume boundaries for each RF. Similar but less pronounced increases were observed for CO. Ozone concentrations within the plume gradually increased with increasing distance from the city. Within 

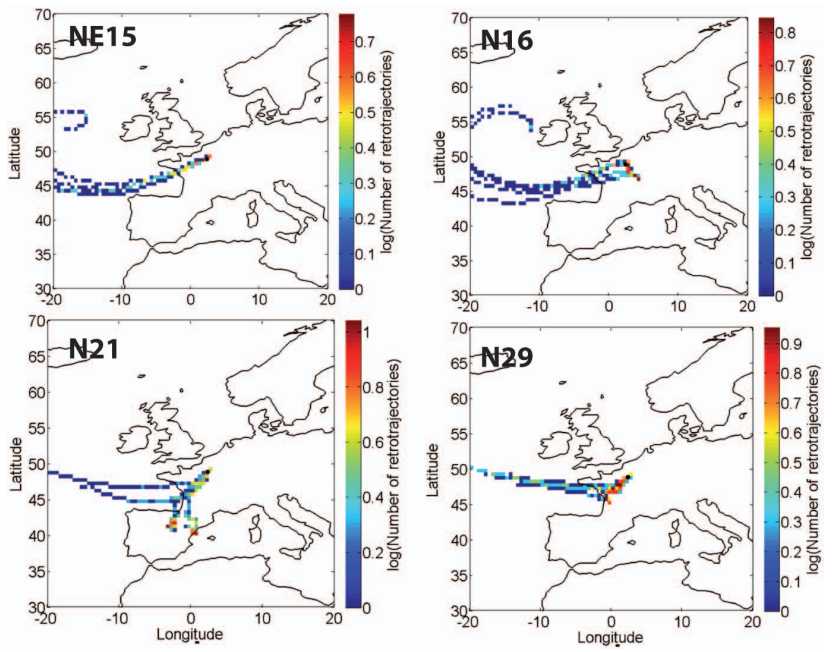

Fig. 1. Air mass backward trajectories calculated using HYSPLIT for $72 \mathrm{~h}$. HYSPLIT trajectories are calculated at a height of $700 \mathrm{~m}$ in the HYSPLIT model. Colour scale is used to indicate the log of the number of back trajectories that pass over a given area (pixel) of $0.5^{\circ} \times 0.5^{\circ}$.

the centre of the plume where $\mathrm{NO}, \mathrm{NO}_{2}$, and $\mathrm{NO}_{\mathrm{y}}$ concentrations were highest, there were decreases in $\mathrm{O}_{3}$ concentration (Fig. 2b), showing that $\mathrm{O}_{3}$ was being rapidly consumed in the reaction:

$\mathrm{NO}+\mathrm{O}_{3} \rightarrow \mathrm{NO}_{2}+\mathrm{O}_{2}$.

Measured gas-phase species $\left(\mathrm{NO}_{\mathrm{x}} / \mathrm{NO}_{\mathrm{y}}\right)$ are used as a proxy for the photochemical age of the air masses around Paris. In general, lower values of $-\log \left(\mathrm{NO}_{\mathrm{x}} / \mathrm{NO}_{\mathrm{y}}\right)$ represent air masses closer to the source and as the air mass becomes more aged, $-\log \left(\mathrm{NO}_{\mathrm{x}} / \mathrm{NO}_{\mathrm{y}}\right)$ approaches 1 (e.g. Kleinman et al., 2008). During the MEGAPOLI experiment, aircraft measurements were made within $200 \mathrm{~km}$ from the centre of Paris, resulting in plume concentrations of $-\log \left(\mathrm{NO}_{\mathrm{x}} / \mathrm{NO}_{\mathrm{y}}\right)$ that only varied between 0.04 and 0.7 . Other airborne studies (MILAGRO) measured up to $600 \mathrm{~km}$ from the source area and the subsequent $-\log \left(\mathrm{NO}_{\mathrm{x}} / \mathrm{NO}_{\mathrm{y}}\right)$ ranged from 0.1 to 1 (DeCarlo et al., 2008). Photochemistry within both Paris and Mexico City are thought to be VOC limited (Song et al., 2010; Deguillaume et al., 2008). VOC measurements show increases in measured concentrations of anthropogenic marker peaks (Toluene, Benzene, $\mathrm{C} 8$-aromatics) within the urban plume. However, biogenic marker peaks (isoprene) did not show peaks within the plume (Fig. S4). More details on the airborne VOC measurements during MEGAPOLI are described in Borbon et al. (2012).

RFs were classified based on flight direction. Measured $\mathrm{PM}_{1}$ mass concentrations (mass concentration measured by the C-ToF-AMS and BC mass concentrations) during each research flight were strongly dependent on the air mass trajectory and the air mass residence time over land. Four of the northern flights (N13, N16, N21, N29) and one of the northeastern flights (NE28) were classified as highly polluted with highest average $\mathrm{PM}_{1}$ mass concentrations within the plume $\left(6.3 \pm 3.3 \mu \mathrm{g} \mathrm{m}^{-3}\right)$ and highest fractions of organic aerosol $(>50 \%)$ (Figs. 2, 3). Air masses sampled during northern flights arrived from a southerly direction and spent the majority of time over land. During northern flights, wind speeds measured downtown of Paris (site) at $40 \mathrm{~m}$ and $200 \mathrm{~m}$ using a mast were $3.78 \pm 0.53 \mathrm{~ms}^{-1}$ and $6.36 \pm 1.9 \mathrm{~ms}^{-1}$, respectively. All of these flights took place during days with no clouds and high temperatures $\left(30^{\circ} \mathrm{C}\right)$, conditions where photochemical production is thought to be high. RFs that were classified as low pollution included one northeastern flight (NE15) and the two eastern flights (E20 and E25) (Table 1). Eastern flights had similar contributions from both $\mathrm{SO}_{4}$ and organic-bearing particles. These flights corresponded to westerly and southwesterly wind regimes with marine air advected to the Paris region. Lower pollution flights had slightly higher average wind speeds of $4.6 \pm 0.9 \mathrm{~ms}^{-1}$ at $40 \mathrm{~m}$ and $7.54 \pm 1.8 \mathrm{~ms}^{-1}$ at $200 \mathrm{~m}$. These observations are similar to those made at the ground-based sites (Freutel et al., 2013), where the highest mass concentrations were measured when air masses arrived from the continent with lower wind speeds. Lower mass concentrations were measured when air masses arrived from the Atlantic with higher wind speeds. Higher wind speeds lead to greater dilution of primary species such as $\mathrm{BC}, \mathrm{HOA}$, and $\mathrm{NO}_{\mathrm{x}}$.

We calculated the difference between the background $\mathrm{PM}_{1}$ mass concentrations (C-ToF-AMS and $\mathrm{BC}$ ) and the inplume $\mathrm{PM}_{1}$ mass concentrations for all species (Table 2) in order to determine the composition of the Paris urban plume corrected for the background aerosol $(\Delta \mathrm{C})$. The plume composition was characterized by high fractions of organics $(\mathrm{N}=48 \%, \mathrm{E} / \mathrm{NE}=54 \%), \mathrm{BC}(\mathrm{N}=22 \%, \mathrm{E} / \mathrm{NE}=15 \%)$, $\mathrm{NO}_{3}(\mathrm{~N}=17 \%, \mathrm{E} / \mathrm{NE}=19 \%)$. As will be discussed in more detail in Sect. 3.2, the organic aerosols were made up of three different types of organic species, a low-volatile oxidized organic aerosol (LV-OOA), a semi-volatile oxidized organic aerosol (SV-OOA), and a hydrocarbon organic aerosol (HOA). For $\mathrm{N}$ flights, organics were composed of $34 \% \mathrm{LV}$ OOA, $27 \%$ SV-OOA, and $39 \% \mathrm{HOA}$; and for E flights, $33 \%$ LV-OOA, $33 \%$ SV-OOA, and $34 \%$ HOA. The contributions of $\mathrm{SO}_{4}$ were more important during $\mathrm{E}$ flights $(20 \%)$ than $\mathrm{N}$ flights $(6 \%)$.

In several RFs the measured mass concentrations of $\mathrm{SO}_{4}$ particles were higher on the northern sector outside of the plume than inside of the plume (Figs. 3, 4). Air mass transport patterns show that these days had air masses that arrived from the west, spending several days over the sea before arriving in Paris (Fig. 1). This type of air mass likely accumulated high concentrations of marine aerosol particles as well as emissions from the shipping channel. This is in agreement with ground-based measurements where $\mathrm{SO}_{4}$ aerosol often correlated with a marine organic aerosol component, suggesting that a large source of aerosol sulfate was from an oceanic source (Crippa et al., 2013b). However, 

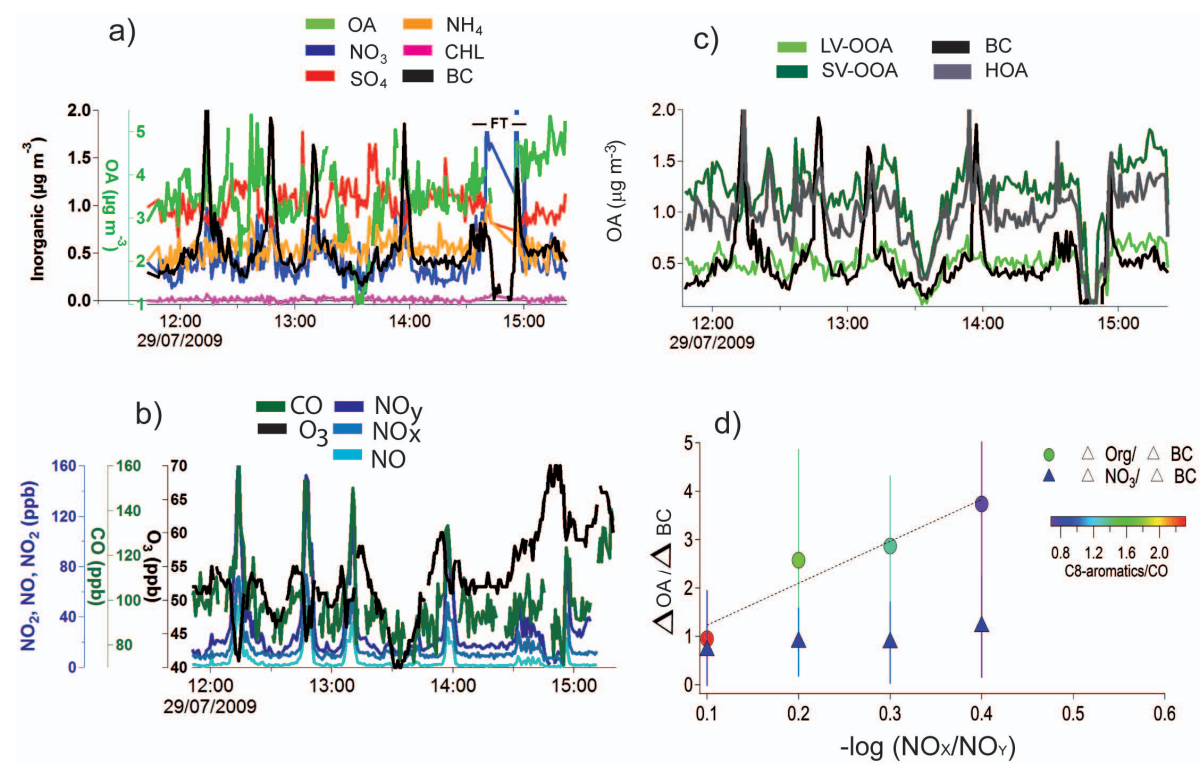

Fig. 2. An overview of aerosol gas and particle composition measured during N29. (a) Time series of AMS particle composition and BC (in black). (b) Time series of gas-phase measurements, (c) PMF analysis of the organic aerosol mass spectra with BC, and (d) increase in the normalized organic aerosol mass concentration as a function of photochemical age.

Table 1. Research flight (RF) number, date and principal measurements available during each flight. Total aerosol concentrations inside and outside the urban plume, and percentage of organic contribution and mass concentrations of BC measured within the plume.

\begin{tabular}{|c|c|c|c|c|c|c|c|}
\hline \multirow[t]{2}{*}{ RF } & \multirow[t]{2}{*}{ Date } & \multicolumn{2}{|c|}{ Mass concentration } & \multirow[t]{2}{*}{$\mathrm{OA} \%$} & \multirow{2}{*}{$\begin{array}{l}\text { BC } \\
\left(\mu \mathrm{g} \mathrm{m}^{-3}\right)\end{array}$} & \multirow{2}{*}{$\begin{array}{l}\text { Flight } \\
\text { sector }\end{array}$} & \multirow{2}{*}{$\begin{array}{l}\text { Flight } \\
\text { classification }\end{array}$} \\
\hline & & Plume & Background & & & & \\
\hline 28 & $13 / 07 / 09$ & 3.36 & 2.69 & 47 & 0.54 & $\mathrm{~N}$ & N13 \\
\hline 29 & $15 / 07 / 09$ & 3.21 & 2.41 & 40 & 0.28 & $\mathrm{NE}$ & NE15 \\
\hline 30 & $16 / 07 / 09$ & 5.85 & 4.37 & 55 & 0.79 & $\mathrm{~N}$ & N16 \\
\hline 31 & $20 / 07 / 09$ & 7.34 & 6.61 & 45 & 0.4 & $\mathrm{E}$ & E20 \\
\hline 32 & $21 / 07 / 09$ & 10.9 & 8.8 & 75 & 1.04 & $\mathrm{~N}$ & N21 \\
\hline 33 & $25 / 07 / 09$ & 4.18 & 3.16 & 33 & 0.28 & $\mathrm{E}$ & E25 \\
\hline 35 & $28 / 07 / 09$ & 6.93 & 4.52 & 55 & 0.62 & $\mathrm{NE}$ & NE28 \\
\hline 36 & 29/07/09 & 3.02 & 2.89 & 65 & 0.94 & $\mathrm{~N}$ & N29 \\
\hline
\end{tabular}

during airborne measurements these $\mathrm{SO}_{4}$ mass concentrations were observed to decrease as soon as the aircraft encountered the urban plume, and when organic, nitrate, and $\mathrm{BC}$ aerosols began to increase. In order to illustrate this more clearly, we included plots of $\mathrm{SO}_{4}$ and Org mass concentrations as a function of longitude (Fig. 4c concentration vs. longitude) and latitude (Fig. 4f latitude vs. concentration). Backward trajectories calculated for several points along the flight track suggest that all air masses arrived from the same source. Other possible explanations could be sulphate formation through secondary processes from anthropogenic $\mathrm{SO}_{2}$ arriving from Le Havre (the nearby shipping port), which might have resulted in a higher background of $\mathrm{SO}_{4}$ aerosol particles. Another possibility is that there were competing processes within the plume that favoured the formation of particulate organic and $\mathrm{NO}_{3}$ over $\mathrm{SO}_{4}$.
In the atmosphere, $\mathrm{H}_{2} \mathrm{SO}_{4}$ is formed principally in the liquid phase but also in the gas phase through the reaction of $\mathrm{SO}_{2}$ with $\mathrm{OH}$ (Eq. 3). $\mathrm{HNO}_{3}$ is formed through reaction of $\mathrm{NO}_{2}$ with $\mathrm{OH}$ (Eq. 4). These reactions have very different reaction rates, with the reaction of $\mathrm{NO}_{2}$ with $\mathrm{OH}\left(1 \times 10^{-11} \mathrm{~cm}^{3}\right.$ molecules $\left.{ }^{-1} \mathrm{~s}^{-1}\right)$ being an order of magnitude higher than that of $\mathrm{SO}_{2}+\mathrm{OH}(1 \times$ $10^{-12} \mathrm{~cm}^{3}$ molecules ${ }^{-1} \mathrm{~s}^{-1}$ ) (Atkinson and Arey, 2003). VOCs present in the atmosphere can also be oxidized by $\mathrm{OH}$, with some of these species, such as large saturated organics, being oxidized by the same order of magnitude as $\mathrm{NO}_{2}$ (Atkinson and Arey, 2003). Therefore, VOCs and $\mathrm{NO}_{2}$ within the plume would possibly compete with $\mathrm{SO}_{2}$ for the 
Table 2. Particle compositions inside and outside of the plume. All concentrations are in $\mu \mathrm{g} \mathrm{m}^{-3}$.

\begin{tabular}{lrrrrrrrrrrrl}
\hline \multirow{2}{*}{ Date } & \multicolumn{3}{c}{$\mathrm{OA}$} & \multicolumn{2}{c}{$\mathrm{SO}_{4}$} & \multicolumn{2}{c}{$\mathrm{NH}_{4}$} & \multicolumn{2}{c}{$\mathrm{NO}_{3}$} & \multicolumn{2}{c}{ Chl } & \multirow{2}{*}{ Classification } \\
\cline { 2 - 10 } & In & Out & In & Out & In & Out & In & Out & In & Out & \\
\hline $13 / 07 / 09$ & 2.49 & 1.54 & 0.96 & 1.22 & 0.53 & 0.56 & 0.43 & 0.217 & $<0.01$ & 0.01 & N13 \\
$15 / 07 / 09$ & 1.35 & 0.74 & 1.13 & 1.09 & 0.44 & 0.42 & 0.27 & 0.14 & $<0.01$ & 0.02 & NE15 \\
$16 / 07 / 09$ & 3.24 & 2.41 & 1.42 & 1.23 & 0.65 & 0.48 & 0.54 & 0.23 & 0.21 & 0.01 & N16 \\
$20 / 07 / 09$ & 1.75 & 1.34 & 1.14 & 1.27 & 0.48 & 0.52 & 0.29 & 0.17 & 0.01 & 0.01 & E20 \\
$21 / 07 / 09$ & 8.42 & 6.49 & 1.18 & 1.35 & 0.64 & 0.59 & 0.70 & 0.39 & 0.02 & 0.01 & N21 \\
$25 / 07 / 09$ & 1.16 & 0.76 & 2.00 & 1.63 & 0.74 & 0.61 & 0.28 & 0.15 & 0.01 & 0.01 & E25 \\
$28 / 07 / 09$ & 3.58 & 2.37 & 1.42 & 1.28 & 0.87 & 0.57 & 1.05 & 0.30 & 0.02 & $<0.01$ & NE28 \\
$29 / 07 / 09$ & 1.97 & 1.90 & 0.47 & 0.48 & 0.28 & 0.27 & 0.31 & 0.23 & 0.01 & $<0.01$ & N29 \\
\hline
\end{tabular}
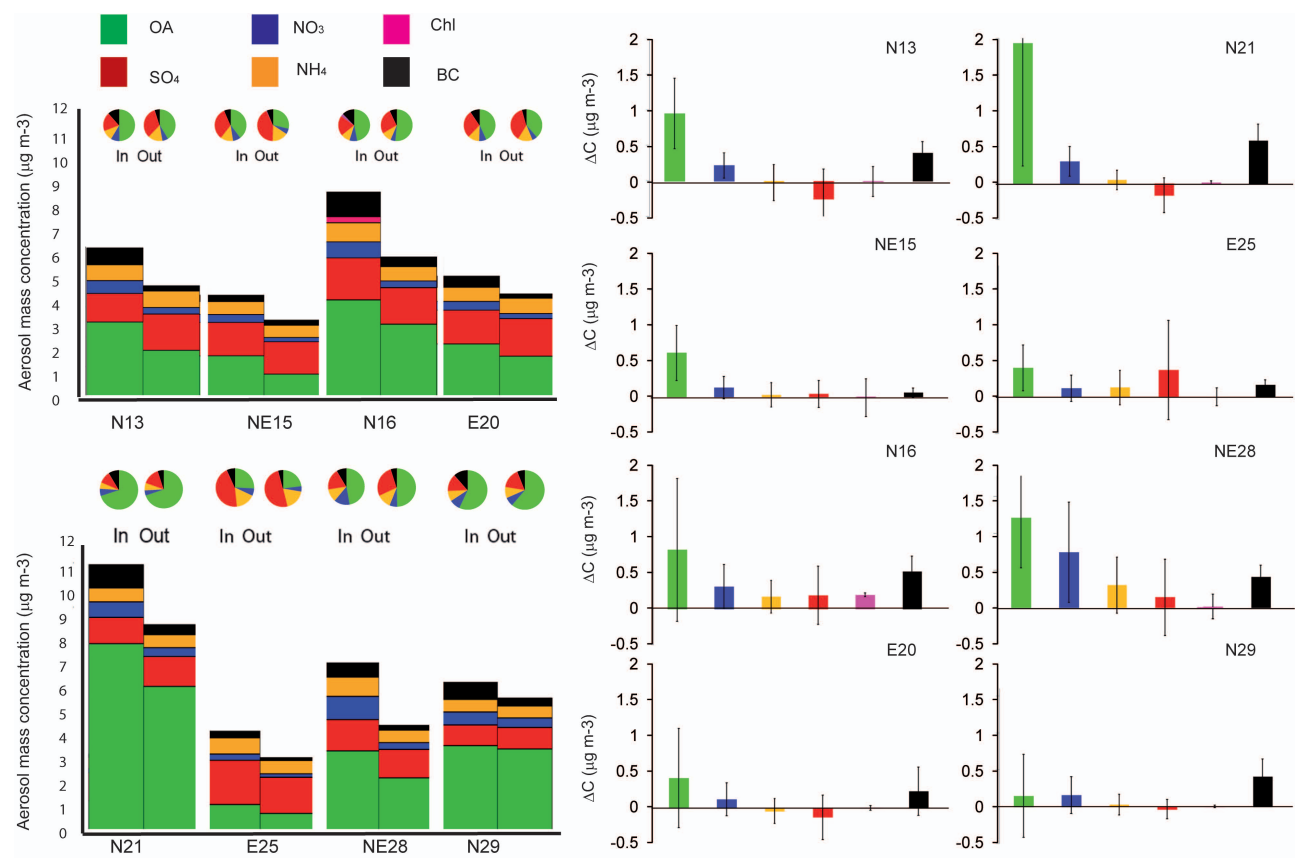

Fig. 3. The left-hand side of the figure shows the aerosol composition measured inside and outside of the plume during each research flight. On the right-hand side the average difference in composition $(\Delta \mathrm{C})$ between the inside and the outside of the urban plume for each flight is shown. Error bars are the $\pm 1 \sigma$ standard deviations.

available $\mathrm{OH}$.

$\mathrm{SO}_{2}+\mathrm{OH}^{\bullet}+\mathrm{M} \rightarrow \mathrm{M}+\mathrm{HOSO}_{2}$

$\mathrm{NO}_{2}+\mathrm{OH}^{\bullet}+\mathrm{M} \rightarrow \mathrm{M}+\mathrm{HNO}_{3}$

Since $\mathrm{SO}_{2}$ measurements were not available during the MEGAPOLI experiment, it is difficult to conclude which gas-phase processes dominate within the plume. However, given the high concentrations of $\mathrm{NO}_{2}, \mathrm{NO}$, and $\mathrm{VOC}$ species within the plume, it is likely that $\mathrm{NO}, \mathrm{NO}_{2}$, and VOC species play an important role in the gas-phase chemistry, reacting preferentially with $\mathrm{OH}$ to form $\mathrm{HNO}_{3}$ and organic aerosol particles at the expense of $\mathrm{H}_{2} \mathrm{SO}_{4}$. This hypothesis could be supported by observations from laboratory studies (Berndt et al., 2008), showing that at high $\mathrm{NO}_{\mathrm{x}}$ concentrations, the formation of new particles from the reaction of $\mathrm{OH}$ radicals with $\mathrm{SO}_{2}$ is inhibited. However, once formed, $\mathrm{H}_{2} \mathrm{SO}_{4}$ is a stronger acid than $\mathrm{HNO}_{3}$ and will be neutralized preferentially to $\left(\mathrm{NH}_{4}\right)_{2} \mathrm{SO}_{4}$.

\subsection{Organic aerosol particles}

In all the $\mathrm{N}$ flights, organic aerosol was the particle composition contributing up to $50 \%$ to the total measured aerosol mass composition. Similar to the method described by $\mathrm{Ng}$ et al. (2010), we plotted the contribution of $m / z 44$ to the total organic mass concentration $\left(f_{44}\right)$ against the contribution of $\mathrm{m} / \mathrm{z}, 43$ to the total organic mass concentration $\left(f_{43}\right)$ in a triangular space for each of the $\mathrm{N}$ research flights (Fig. 5) and for each of the E or NE flights (Fig. S6). $F_{44}$ corresponds 

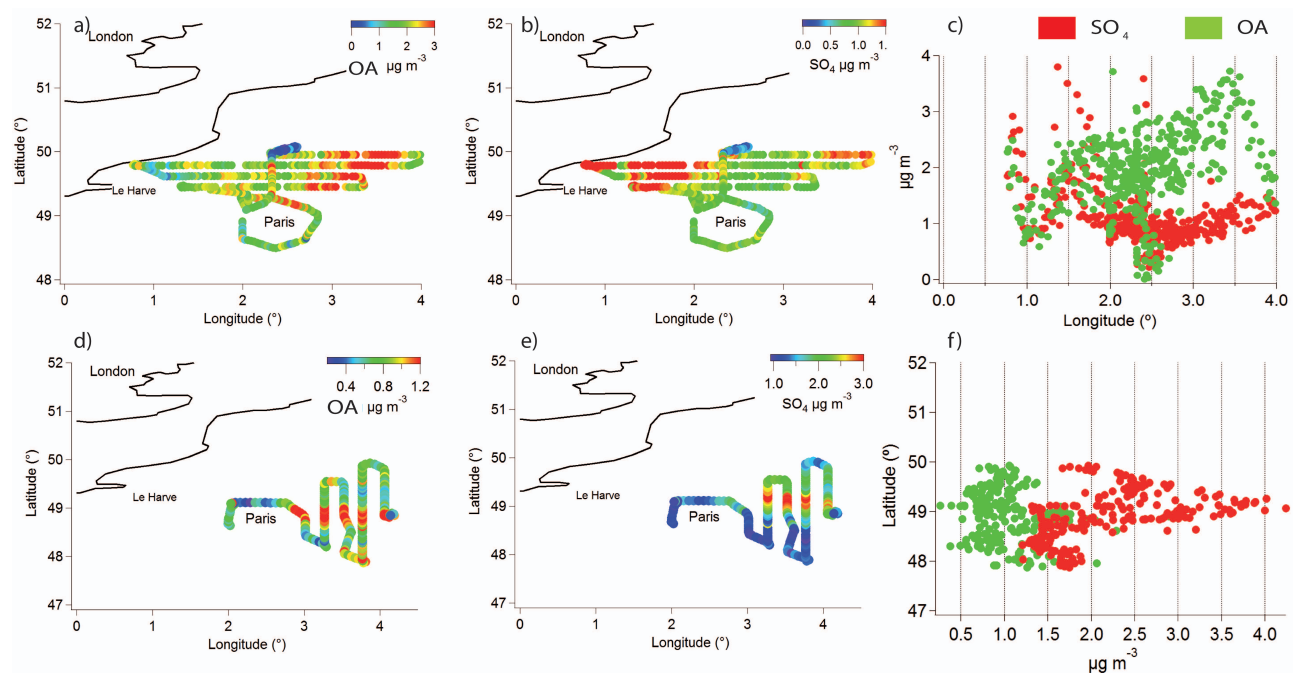

Fig. 4. Flight tracks over the Paris region for $\mathrm{N} 13$ (a, b) and E25 (c, d) coloured by $\mathrm{SO}_{4}(\mathbf{b}, \mathbf{e})$ and OA (a, d). (c) and (f) show OA vs. longitude and latitude vs. $\mathrm{SO}_{4}$, respectively.

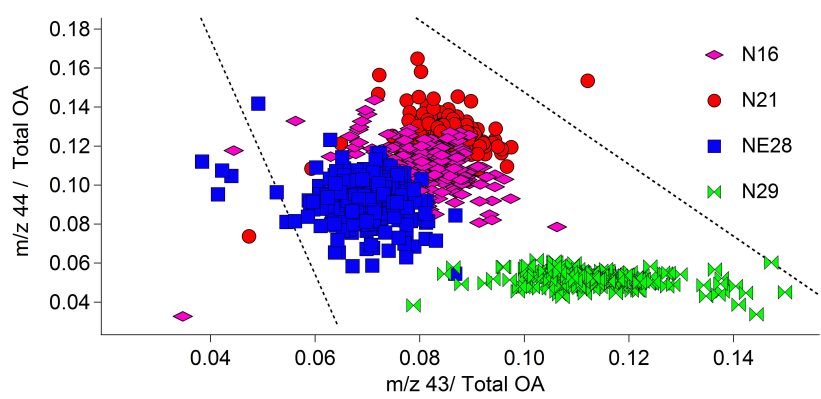

Fig. 5. Fraction of OA44 to total OA $\left(f_{44}\right)$ against the fraction of OA 43 to total OA $\left(f_{43}\right)$ for N16, N21, NE28, and N29. The black dotted lines show boundaries set by $\mathrm{Ng}$ et al. (2010).

mainly to the oxidized mass fragment $\left(\mathrm{CO}_{2}^{+}\right)$while $f_{43}$ corresponds to a hydrocarbon fragment $\left(\mathrm{C}_{3} \mathrm{H}_{7}^{+}\right)$. The black dotted lines in the figures show boundaries determined from a comparison of an ensemble of secondary organic aerosol measurements conducted in the Northern Hemisphere ( $\mathrm{Ng}$ et al., 2010). In general, as the organic aerosol becomes more aged (oxidized), the $f_{44}$ increases with all points approaching the top of the triangle. The fraction of $f_{44}$ measured by the $\mathrm{C}$ ToF-AMS is always less than 0.15 but more than 0.05 , which is characteristic of semi- to low-volatile organic species. One exception to this was the $\mathrm{N} 29$ flight where the $f_{44}$ of the aerosol was lower than the other northern flights, showing a much less oxidized organic aerosol. In contrast to $\mathrm{Ng}$ et al. (2010), all organic aerosols (primary and secondary) are included.

Organic aerosol particles measured during each of the $\mathrm{N}$ flights have different and isolated properties based on the $f_{44}$ versus $f_{43}$ signals. The $\mathrm{E}$ and NE flights, however, showed organic aerosols with similar properties for each flight (Fig. S5). The two flights with the largest difference were N21 and N29. These two flights were both northern sector flights and had BC values measured within the urban plume $>0.9 \mu \mathrm{g} \mathrm{m}^{-3}$. Both flights had a high contribution of organics $(>45 \%)$. However, N21 $\left(\mathrm{Org}=6.5 \mu \mathrm{g} \mathrm{m}^{-3}\right)$ had considerably higher background organic mass concentrations (and higher $f_{44}$ values) than $\mathrm{N} 29\left(\mathrm{Org}=1.9 \mu \mathrm{g} \mathrm{m}^{-3}\right)$. The contributions from inorganic aerosols were similar (average inorganics $30 \% \pm 5 \%$ ). The maximum photochemical age of these flights, determined using the value of $-\log \left(\mathrm{NO}_{\mathrm{x}} / \mathrm{NO}_{\mathrm{y}}\right)$, showed that the pollution measured during N21 was far more aged (0.63) than during N29 (0.35). Air mass back trajectories of N21 showed that the air masses spent at least two days over SW France and Spain and likely picked up SOA there, which resulted in a higher organic aerosol background. Air masses arriving during N29 had the same origin but with a shorter continental residence time (Fig. 1). This resulted in a lower level of background aerosol and a much larger contribution from urban emissions within Paris and therefore a much less oxidized aerosol.

The combination of inorganic and organic aerosol measurements during different meteorological periods shows that aerosol mass concentrations measured in Paris are strongly influenced by regional air-mass history, as was already observed from ground-based measurements (Freutel et al., 2013). However, increases in aerosol mass concentrations within the plume show that anthropogenic emissions from the centre of Paris affect the mass concentrations and composition of the aerosol at least up to the distance $(200 \mathrm{~km})$ measured during this study. The composition and evolution of the organic aerosol is discussed in more detail in the following sections. 


\subsubsection{Positive matrix factorization analysis}

PMF analysis was performed on the ensemble organic mass spectra of all flights in order to extract different groups of organic aerosol. The resulting solutions were evaluated with respect to the statistical analyses and through comparison with supplementary particle and gas-phase measurements. A three-factor solution was chosen to best represent the organic mass spectra measured during the MEGAPOLI experiment. Increasing the number of factors to four neither improved the weighted residual analysis nor resulted in any substantial gain in the correlations of the factor time series and factor profiles compared to external species. (Tables S2, S3, S4). Different solutions were explored using the global rotational tool $f_{\text {peak }}$ within a range -1 to 1 . Reasonable solutions lay in the $f_{\text {peak }}$ range from -0.2 to 0.2 ; the solution with $f_{\text {peak }}=0.2$ was chosen to best represent the data. Correlations of the three-factor solution as a function of three $f_{\text {peak }}(0.2,0$, and -0.2$)$ values are listed in Table S6. $Q / Q_{\text {exp }}$ values as a function of $f_{\text {peak }}$ values show lowest values for an $f_{\text {peak }}$ of 0 , but only vary between 0.005 for an $f_{\text {peak }}$ of -0.2 and 0.2 (Fig. S10). More significant differences between mass spectral correlations were observed for an $f_{\text {peak }}$ solution of 0.2 compared with those with an $f_{\text {peak }}$ of 0 and -0.2 .

The resolved mass spectra and correlations for the twoand four-factor solutions are shown in the Supplement. The three PMF factors included a primary/hydrocarbon organic aerosol (HOA), a semi-volatile oxidized organic aerosol (SVOOA), and a low-volatile oxidized organic aerosol (LVOOA). The HOA made up approximately $30 \% \pm 13 \%$ of the resolved PMF factors. The resolved HOA mass spectra had no contribution from $\mathrm{m} / \mathrm{z}, 44$ but had significant contributions from $m / z 43\left(f_{43}=0.09\right)$ and from $m / z 55$ $\left(f_{55}=0.08\right)$ as well as $m / z 57\left(f_{57}=0.03\right)$ (Figs. S7 to S9) and correlated with the reference mass spectra for HOA ( $\mathrm{Ng}$ et al., 2011); (Pearsons $r\left(P_{\mathrm{R}}\right)=0.88$ ) correlations with reference mass spectra of LV-OOA and of SV-OOA are less than $P_{\mathrm{R}}=0.35$ and 0.78 , respectively. The temporal evolution of the HOA species correlated with primary particulate and gas-phase species such as $\mathrm{BC}\left(P_{\mathrm{R}}=0.65 \pm 0.17\right)$ and toluene $\left(P_{\mathrm{R}}=0.52 \pm 0.14\right)$. Above the city of Paris we might not expect to resolve a primary organic species; however, the measured contribution of the resolved HOA species to the total aerosol mass concentration (C-ToF-AMS + BC) is $11 \pm 7 \%$, which is similar to the contributions of primary BC particles measured in the Paris plume $(7 \pm 5 \%)$. At the ground sites a cooking OA was resolved and contributed between 10 and $30 \%$ to the total measured OA. At altitude we were unable to separate these factors, but they could possibly be included within the HOA. The SV-OOA correlated with reference mass spectra SV-OOA and LV-OOA ( $\mathrm{Ng}$ et al., 2011) ( $P_{\mathrm{R}}=0.78$ and $P_{\mathrm{R}}=0.77$, respectively) and had contributions from $m / z 43\left(f_{43}=0.13\right), m / z 44\left(f_{44}=0.18\right)$, and from $m / z 55\left(f_{55}=0.02\right)$ (Figs. S7 to S9). The SV-
OOA species also correlated with primary marker species $\mathrm{BC}\left(P_{\mathrm{R}}=0.58 \pm 0.11\right)$ and toluene $\left(P_{\mathrm{R}}=0.43 \pm 0.14\right)$. The LV-OOA had high contributions of $m / z 44\left(f_{44}=0.32\right)$ and low contributions from primary marker peaks such as $m / z$ $43\left(f_{43}=0.09\right)$ and $m / z 55\left(f_{55}=0.02\right)$. In addition, it correlated well with reference mass spectra for LV-OOA $\left(P_{\mathrm{R}}=\right.$ 0.83). Correlations with temporal evolution of $\mathrm{SO}_{4}$ particles are low. This is expected since the majority of the $\mathrm{SO}_{4}$ mass is measured outside of the urban plume boundaries and a large fraction of the organic aerosol is measured inside the urban plume boundaries.

The organic mass spectra were further explored with the ME-2 tool (Canonaco et al., 2013) by constraining the factor profiles of the primary species cooking and marine that has been modelled with ground-based measurements during the same period of measurement (Crippa et al., 2013). However, the time dependence of the marine factor was not correlated with the ground-based data and the inclusion of cooking deteriorated the correlation of $\mathrm{BC}$ and HOA. Therefore, only the PMF solution with three factors is considered here.

\subsubsection{Analysis of the organic build-up within the plume}

Several studies (Volkamer et al., 2006; Kleinman et al., 2008; DeCarlo et al., 2010) have shown that the OA increases rapidly with the air mass photochemical age. During this study the photochemical age of the air masses is approximated using gas-phase measurements $\left(\mathrm{NO}_{\mathrm{x}} / \mathrm{NO}_{\mathrm{y}}\right)$. $\mathrm{NO}_{\mathrm{x}} / \mathrm{NO}_{\mathrm{y}}$ measurements were available during four RFs (E20, N21, NE28, N29). Among these four flights, only two (N21 and N29) had simultaneous measurements of aerosol composition (C-ToF-AMS) and VOCs (PTR-MS) (Table S1). When using $\mathrm{NO}_{\mathrm{x}}$ and $\mathrm{NO}_{\mathrm{y}}$ measurements as an indicator of photochemical age, it is necessary to assure that there are not multiple sources of $\mathrm{NO}_{\mathrm{x}}$ emissions that would result in an incorrect measurement of the photochemical age. During the MEGAPOLI experiment, increases in $\mathrm{NO}_{\mathrm{y}}, \mathrm{NO}_{\mathrm{x}}$ and other gas-phase species were only observed within the plume boundaries. It is therefore assumed that the calculated photochemical age is representative of urban emissions from Paris, and that there are no nearby sources of pollution contributing to the increases in $\mathrm{NO}_{\mathrm{y}}$ and $\mathrm{NO}_{\mathrm{x}}$ observed during the measurement period (Figs. 2, S3).

Aerosol measurements are most commonly normalized with measurements of CO. During our measurement period the difference between the background and local $\mathrm{CO}$ measurements and the absolute $\mathrm{CO}$ concentrations were low $(<150 \mathrm{ppb})$. In Paris, background values of $\mathrm{CO}$ ranging between $90 \mathrm{ppb}$ and $110 \mathrm{ppb}$ were measured, and increases above background ranged from $10 \mathrm{ppb}$ up $\sim 60 \mathrm{ppb}$, with average variations of about $25 \mathrm{ppb}$. Figures presented in McMeeking et al. (2012) suggest background concentrations of CO varied from 100 to $120 \mathrm{ppb}$, and increases above background ranged from 20 up to $80 \mathrm{ppb}$ with average variations of around $30 \mathrm{ppb}$. Compared with Mexico 
City (DeCarlo et al., 2010; Kleinman et al., 2008), these values of $\mathrm{CO}$ and $\triangle \mathrm{CO}$ are low. However, compared with London, these measurements appear to be representative of European air masses. For this reason, our initial calculations used $\mathrm{BC}$ to normalize aerosol measurements. As noted by Park et al. (2005), BC mixed with soluble aerosol particles could be susceptible to wet deposition. In good weather conditions, wet deposition is not likely to be important and the BC concentration should be conserved. For this study we believe that any decrease in $\mathrm{BC}$ concentration with photochemical age of the pollution plume is a result of air mass dilution. Background values of Org, LV-OOA, SV-OOA, HOA, and $\mathrm{BC}$ were used to calculate the increase in the organic $(\Delta \mathrm{Org})$ and $\mathrm{BC}(\triangle \mathrm{BC})$ mass concentrations resulting from the urban plume.

Increases in $\mathrm{OA}(\triangle \mathrm{OA})$ and $\mathrm{NO}_{3}\left(\Delta \mathrm{NO}_{3}\right)$ above background are normalized to $\triangle \mathrm{BC}$. The ratios of $\triangle \mathrm{OA} / \triangle \mathrm{BC}$ and $\triangle \mathrm{NO}_{3} / \triangle \mathrm{BC}$ are then averaged over seven different subsets of photochemical age ranging from 0 to $>0.6$ at intervals of 0.1 . For each research flight we observe increases in $\triangle \mathrm{OA} / \Delta \mathrm{BC}$ with increasing $-\log \left(\mathrm{NO}_{\mathrm{x}} / \mathrm{NO}_{\mathrm{y}}\right)$ (Fig. S3d). In comparison, the $\Delta \mathrm{NO}_{3} / \triangle \mathrm{BC}$ shows little change as the photochemical age increases. These increases in OA so close to the source of the urban plume illustrate that OA is being formed from anthropogenic emissions from the Paris region. These observations are in agreement with recent studies by Chirico et al. (2010) and Platt et al. (2013), who demonstrated that SOA from diesel and gasoline vehicles are rapidly formed.

In order to examine how the different types of OA change as a function of photochemical age, we compared the three OA types $(\Delta \mathrm{LV}-\mathrm{OOA} / \triangle \mathrm{BC}, \Delta \mathrm{SV}-\mathrm{OOA} / \Delta \mathrm{BC}$, and $\triangle \mathrm{HOA} / \triangle \mathrm{BC})$ with $-\log \left(\mathrm{NO}_{\mathrm{x}} / \mathrm{NO}_{\mathrm{y}}\right)$ values for the four flights: N16, E20, N21, and N29. The averaged ratio of $\triangle \mathrm{LV}-\mathrm{OOA} / \triangle \mathrm{BC}$ and the $\triangle \mathrm{SV}-\mathrm{OOA} / \triangle \mathrm{BC}$ for all flights increase by a factor of 2.12 and 1.98 , respectively, when the $\left(-\log \left(\mathrm{NO}_{\mathrm{x}} / \mathrm{NO}_{\mathrm{y}}\right)\right.$ increased from 0.1 up to 0.6. The $\Delta \mathrm{HOA} / \triangle \mathrm{BC}$ varied slightly, with an average ratio of 1.28 , which is thought to be within the error of the measurements (Fig. 6). Several studies have shown that for urban HOA, evaporation is thought to occur on a timescale of minutes (Zhang and Wexler, 2004), and therefore urban $\mathrm{HOA} /(\mathrm{BC} / \mathrm{CO})$ should not be affected by additional evaporation. In Paris, the ratio appears to be stable, similar to observations made in Mexico City (DeCarlo et al., 2008), where the HOA was conserved over the timescale of the study $(\sim 6 \mathrm{~h})$. However, as suggested by recent observations in the Mediterranean, the HOA might decrease after much more oxidation (Hildebrandt et al., 2010).

\subsubsection{Understanding the production of $\mathrm{OA}$ within the plume}

Similar to previous studies (Kleinman et al., 2008), we attempt to apportion the increase in organic aerosol to certain

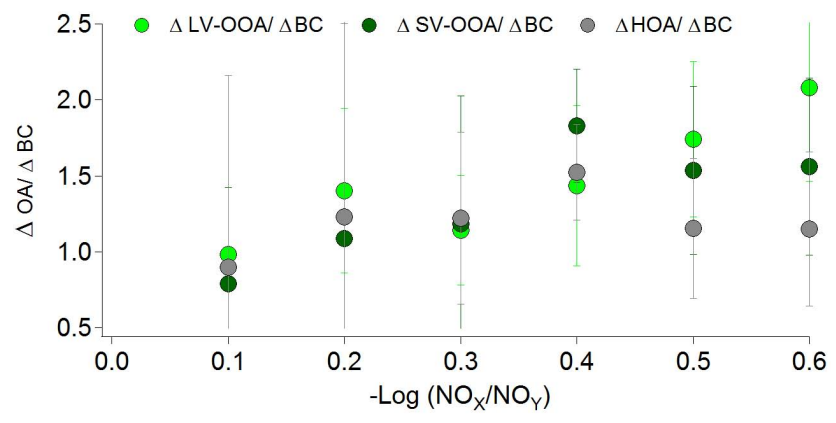

Fig. 6. The ratio $( \pm 1 \sigma)$ of $\Delta \mathrm{LV}-\mathrm{OOA} / \Delta \mathrm{BC}, \Delta \mathrm{SV}-\mathrm{OOA} / \Delta \mathrm{BC}$, and $\triangle \mathrm{HOA} / \triangle \mathrm{BC}$ as a function of photochemical age $\left(-\log \left(\mathrm{NO}_{\mathrm{x}} / \mathrm{NO}_{\mathrm{y}}\right)\right.$.

types of aerosol sources. We first recalculate the increase in $\mathrm{OA}$ relative to $\mathrm{CO}$ rather than to $\mathrm{BC}$, allowing us to compare with other studies and to compare with the formation of secondary organic aerosol resulting from gas-phase precursors. However, Fig. 7 illustrates that, similar to the $\triangle \mathrm{OA} / \triangle \mathrm{BC}$, the $\triangle \mathrm{OA} / \triangle \mathrm{CO}$ ratio increases with photochemical age. The addition of OA to the plume as a result of aging was calculated using Eq. (5):

$(\Delta \mathrm{OA} / \Delta \mathrm{CO})=(\Delta \mathrm{OA} / \Delta \mathrm{CO})_{(\mathrm{X})}-(\Delta \mathrm{OA} / \Delta \mathrm{CO})_{(\mathrm{Y})}$

where $\mathrm{X}$ and $\mathrm{Y}$ represents the photochemical age furthest from the source and nearest to the source, respectively. Using this Eq. (5), we calculated $\Delta \mathrm{OA} / \Delta \mathrm{CO}$ of $70,69,72$, and $65 \mu \mathrm{g} \mathrm{m}^{3} \mathrm{ppm}^{-1} \mathrm{CO}$ for N16, N20, N21, and N29 using a maximum value of $-\log \left(\mathrm{NO}_{\mathrm{x}} / \mathrm{NO}_{\mathrm{y}}\right)$ of $0.6,0.3,0.7$, and 0.3 , respectively (Table 3 ). Assuming that all the organic mass added during photochemical aging is OOA (oxidized organic aerosol) with a carbon content, OC, we can use the ratio $\mathrm{OOA} / \mathrm{OC}=2.2 \mu \mathrm{g} \mu \mathrm{g} \mathrm{C}^{-1}$ (Zhang et al., 2004). Therefore, the carbon added to the aerosol phase during photochemical aging is $31.8,31.3,32.7$, and $29.5 \mu \mathrm{g} \mathrm{C} \mathrm{m} \mathrm{ppm}^{-1}$ $\mathrm{CO}$ for N16, N20, N21, and $\mathrm{N} 29$, respectively.

Corresponding values of $\Delta \mathrm{NO}_{3} / \Delta \mathrm{CO}$ give 23, 19, 10, and $17 \mu \mathrm{g} \mathrm{m}^{3} \mathrm{ppm}^{-1} \mathrm{CO}$ for N16, N20, N21, and N29 using a maximum value of $-\log \left(\mathrm{NO}_{\mathrm{x}} / \mathrm{NO}_{\mathrm{y}}\right)$ of $0.6,0.3,0.7$, and 0.3, respectively. McMeeking et al. (2012) reported values varying between 20 and $30 \mu \mathrm{g} \mathrm{m}^{3} \mathrm{ppm}^{-1} \mathrm{CO}$ in London. These measurements show that the formation of secondary $\mathrm{OA}$ is almost three times more important than the formation of other aerosol species through secondary processes.

Values of $\triangle \mathrm{OA} / \triangle \mathrm{CO}$ calculated from Paris emissions are similar to those measured in a number of different research environments all over the world (Table 3), even though there are large differences in the absolute $\mathrm{CO}$ values observed. deGouw and Jimenez (2009) reported enhancement ratios of $\mathrm{OA}$ relative to $\mathrm{CO}$ for fresh and aged urban emissions and stated that although there are large differences in the absolute $\mathrm{CO}$ concentrations and emission properties, the $\Delta \mathrm{OA} / \triangle \mathrm{CO}$ did not show significant variations $\left(70 \pm 20 \mu \mathrm{g} \mathrm{m}^{3} \mathrm{ppm}^{-1}\right)$. 
Table 3. Comparison of the change in $\triangle \mathrm{OA} / \triangle \mathrm{CO}$ measured in different regions.

\begin{tabular}{|c|c|c|c|c|c|c|c|c|}
\hline \multirow[b]{2}{*}{ Photochemical age } & \multicolumn{6}{|c|}{$\Delta \mathrm{OA} / \Delta \mathrm{CO} \mu \mathrm{g} \mathrm{m}^{-3} \mathrm{ppm} \mathrm{CO}$} & \multirow[b]{2}{*}{ NEAQ/ITCT $2004^{\mathrm{c}}$} & \multirow[b]{2}{*}{$\mathrm{EM} 25^{\mathrm{d}}$} \\
\hline & N16 & E20 & N21 & N29 & Mexico City ${ }^{a}$ & NEAQS $2002^{b}$ & & \\
\hline Near source & 40 & 37 & 62 & 32 & 10 & 37 & 6.6 & $9 \pm 3$ \\
\hline After 1 day* & 98 & 101 & 133 & 97 & 73 & 103 & 70 & 50 \\
\hline Change & 58 & 64 & 71 & 65 & 63 & 66 & 63 & 41 \\
\hline Absolute CO & 152 & 138 & 150 & 150 & 2500 & 325 & 325 & $\sim 120$ \\
\hline
\end{tabular}

* For this study the photochemical age $\left(-\log \left(\mathrm{NO}_{\mathrm{x}} / \mathrm{NO}_{\mathrm{y}}\right)\right.$ was maxim 0.6 for $\mathrm{N} 21$ and 0.3 for $\mathrm{N} 29$.

${ }^{a}$ Kleinman et al. (2008).

b Kleinman et al. (2007). The photochemical age in these studies varies from 0.083 to 0.94 .

${ }^{c}$ Sullivan et al. (2006) and Weber et al. (2007).

d McMeeking et al. (2012).

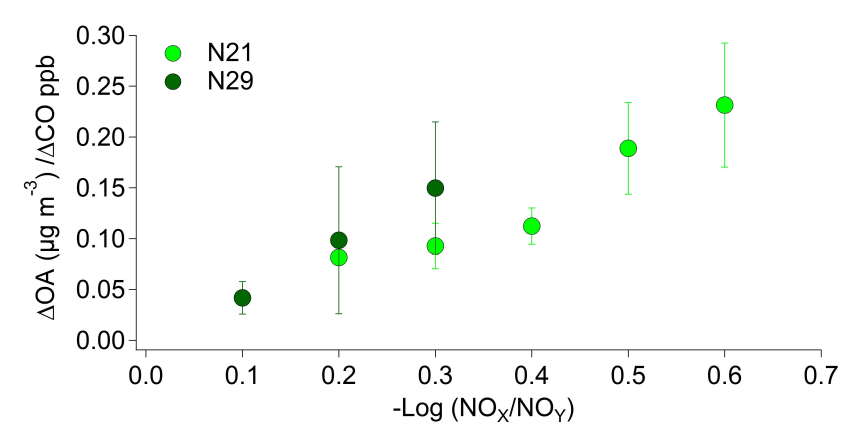

Fig. 7. The change in the $\Delta \mathrm{OA} / \Delta \mathrm{CO}$ for $\mathrm{N} 21$ and for $\mathrm{N} 29$ as a function of photochemical age.

These conclusions were also confirmed by recent London measurements (McMeeking et al., 2012).

In addition to variations in the sources and emissions from region to region (Mexico City and Paris), each of the RFs during MEGAPOLI were exposed to air masses with different histories. RF N21 and N29 are both influenced by southerly air masses; however, the air mass for N21 spent long periods of time over southern France and had much higher background OA concentrations than N29. This is also observed in Table 3 where values of $\triangle \mathrm{OA} / \triangle \mathrm{CO}$ near the source and after aging are higher for N21 than for N29. As noted by Kleinman et al. (2008), it is not known how CO emission sources change from region to region and therefore the $\Delta \mathrm{OA} / \Delta \mathrm{CO} \mu \mathrm{g} \mathrm{m}^{3} \mathrm{ppm}^{-1} \mathrm{CO}$ may not be comparable between studies. However, Table 3 shows that the absolute concentrations of $\mathrm{CO}$ emissions do not have an impact on the production of OA per unit of CO.

As already mentioned in Sect. 2.3, care must be taken when defining background values of OA and CO. For example, for E16, the background value of $\mathrm{CO}$ was chosen to be $87 \mathrm{ppb}$. This was calculated by averaging $\mathrm{CO}$ measurements outside of the plume, in the same way as was done for $\mathrm{BC}$ and $\mathrm{OA}$ (Sect. 2.3). If we increase this background to $97 \mathrm{ppb}$, the $\Delta \mathrm{OA} / \Delta \mathrm{CO} \mu \mathrm{g} \mathrm{m}^{-3} \mathrm{ppm}^{-1} \mathrm{CO}$ increases from 70 to 110 . If the background $\mathrm{CO}$ is decreased to $77 \mathrm{ppb}$, the $\Delta \mathrm{OA} / \Delta \mathrm{CO} \mu \mathrm{g} \mathrm{m}^{-3} \mathrm{ppm}^{-1} \mathrm{CO}$ decreases to 34 . In ad- dition to uncertainties associated with the determination of background values, it is necessary to account for different photochemical ages among the different research flights and among different studies. In New England, USA, and Mexico City, the photochemical ages $\left(-\log \left(\mathrm{NO}_{\mathrm{x}} / \mathrm{NO}_{\mathrm{y}}\right)\right.$ ranged from 0 up to 0.94 ; however, the maximum photochemical ages measured within the plume during this study varied from low values of 0.3 (E20 and N29) up to 0.7 (N16 and N21).

Despite uncertainties in the measurements, the similarities within our results and those from other regions highlights the importance of having simultaneous gas and particle phase measurements available during studies in order to put the formation and aging of secondary organic aerosol particles in the atmosphere into the perspective of emissions.

\subsubsection{Sources of organic aerosol particles within the plume}

A number of field studies have shown that in the atmosphere rapid increases in the formation of SOA were linked to the oxidation of anthropogenic VOCs (Volkamer et al., 2006). The use of C8-aromatics / CO ratio is another proxy of photochemical depletion by anthropogenic VOCs occurring within the Paris plume. Borbon et al. (2013) shows that $\mathrm{C} 8$-aromatics concentrations decreased faster than $\mathrm{CO}$ at the timescale of the Paris plume transport compared to benzene and toluene. This ratio is therefore expected to decrease as photochemical age $\left(-\log \left(\mathrm{NO}_{\mathrm{x}} / \mathrm{NO}_{\mathrm{y}}\right)\right.$ increases, as revealed by the RGB colouring in Fig. S3d for the ratio of $\mathrm{C} 8$-aromatics/CO. This pattern together with measurements showing increases in typical anthropogenic VOC markers peaks within the plume $(\mathrm{m} / z, 93$ (Toluene) $\Delta$ Toluene $_{\mathrm{PLUME}} /$ Toluene $_{\mathrm{BKG}}=109 \pm 40 \%, \mathrm{~m} / \mathrm{z} 79$ (Benzene) $90 \pm 40 \% \Delta$ BenzeneplumE /Benzene BKG $_{\text {, Fig. S5) }}$ suggests that anthropogenic VOC emissions are most likely contributing to the formation of SOA within the plume. Biogenic marker peaks, such as isoprene, did not show significant increases within the plume (Fig. S5) $\left(\Delta\right.$ Isoprene $_{\text {PLUME }} /$ Isoprene $\left._{\mathrm{BKG}}=-5 \pm 5 \%\right)$. 
Using the available VOC measurements, we attempt to estimate the yield of OA that would be produced from the available gas-phase precursors using Eq. (6) for N21 and N29:

$$
\left(\frac{\Delta \mathrm{OA}}{\Delta \mathrm{CO}}\right) \text { predicted }=\left(\frac{\sum \gamma_{i} \cdot \Delta \mathrm{VOC}_{i}}{\Delta \mathrm{CO}}\right)
$$

$\mathrm{VOC}_{i}$ corresponds to the each VOC species $(i)$ used. To calculate the aerosol formation from benzene, toluene, C8aromatics, and $\mathrm{C} 9$-aromatics, we used the yields $\left(\gamma_{i}\right)$ for low concentrations of both $\mathrm{NO}_{\mathrm{x}}$ and $\Delta$ hydrocarbons $(\triangle \mathrm{HC})$ determined by $\mathrm{Ng}$ et al. (2007) (Table S4). Biogenic VOCs were not included in this calculation. The calculated yields result in $80 \pm 3$ ppbC per ppm CO and $32.3 \pm 3.2$ ppbC per ppm CO for N21 and N29, respectively. Predicted values are higher than the $65.4 \mathrm{ppbC}$ per ppm measured for $\mathrm{N} 21$ (Sect. 3.2.3) and represent $54 \%$ of the measured $59 \mathrm{ppbC}$ per ppm for N29. Higher values in N21 may be related to the sparse data points (70\% availability) for N21 compared to N29 (100\% availability). The yields $\left(\gamma_{i}\right)$ used in this study are determined under laboratory conditions. In addition to $\mathrm{NO}_{\mathrm{x}}$ levels, the yields $\left(\gamma_{i}\right)$ are also dependent on concentrations of total organic carbon, which is usually much higher in laboratory studies than under ambient conditions. Therefore, the estimation of the SOA yields provides a sense of the potential impact of anthropogenic VOCs on SOA production within the plume. If we calculate the amount of $\mathrm{OA}$ in the plume using the high $\mathrm{NO}_{\mathrm{x}}$ yields reported in $\mathrm{Ng}$ et al. (2007), similar to those used by Kleinman et al. (2008), our estimated yield of $\triangle \mathrm{OA} / \triangle \mathrm{CO}$ drops to 23 and $9.7 \mathrm{ppbC}$ per ppm CO, representing only $35 \%$ and $15 \pm 1 \%$ of the measured $\triangle \mathrm{OA} / \triangle \mathrm{CO}$. This may partly explain why such a small fraction of the organic mass was accounted for by anthropogenic VOCs in Kleinman et al. (2008) and demonstrates the importance of improving our knowledge of secondary organic aerosol formation processes through controlled laboratory measurements. For this calculation, we only consider the available on board measurements of benzene, toluene, C8aromatics and $\mathrm{C} 9$-aromatics. Nevertheless, aromatics would represent the major SOA anthropogenic precursors compared to organic compounds of lower volatility, as shown by AittHelal et al. (2014) in suburban Paris from ground-based measurements. Since biogenic VOC emissions (isoprene) were similar within and outside of the Paris urban plume, we do not believe that biogenic VOC had a strong impact on the formation of secondary OA. However, biogenic VOC emissions may still play a role in secondary OA formation in the plume through interactions with anthropogenic VOCs (Spracklen et al., 2011; Shilling et al., 2013).

\section{Summary}

Measurements made aboard the ATR-42 during the MEGAPOLI experiment in July 2009 have allowed us to study the composition and evolution of aerosol particle- and gas-phase species as urban emissions leave Paris. Each RF was performed over a relatively small geographical area $(<200 \mathrm{~km})$, allowing rapid changes in aerosol mass concentration to be monitored.

Similar to observations made by Freutel et al. (2013), we observe that largest differences in aerosol concentration and $\mathrm{BC}$ levels are related mainly to air-mass origin. Air masses that had spent the most time over land had higher levels of $\mathrm{BC}$, organic, and nitrate concentrations than westerly airmasses that had spent less time over land. The composition of the urban plume $(\Delta \mathrm{C})$ can be described by high contributions of organic $(\mathrm{N}=48 \%, \mathrm{E} / \mathrm{NE}=54 \%), \mathrm{BC}(\mathrm{N}=22 \%$, $\mathrm{E} / \mathrm{NE}=15 \%)$, and $\mathrm{NO}_{3}(\mathrm{~N}=17 \%, \mathrm{E} / \mathrm{NE}=19 \%)$ particles.

Organic aerosol particles normalized to $\mathrm{BC}$ increased as a function of photochemical age. The plotted ratios of $\mathrm{PMF}$ resolved OA $(\triangle \mathrm{LV}-\mathrm{OOA} / \triangle \mathrm{BC}, \Delta \mathrm{SV}-\mathrm{OOA} / \triangle \mathrm{BC}$, and $\triangle \mathrm{HOA} / \triangle \mathrm{BC}$ ) as a function of photochemical age $\left(-\log \left(\mathrm{NO}_{\mathrm{x}} / \mathrm{NO}_{\mathrm{y}}\right)\right)$ show that increases in $\mathrm{OA}$ are dominated by secondary OA species. As described in Sect. 3, the vertical temperature gradient between the ground sites and that of the aircraft were small; for this reason we do not believe that we can make any conclusions on the impact of temperature on the formation of SV-OOA vs. LV-OOA.

At their ground-based site, Freutel et al. (2013) did not observe a significant increase in OOA between the three different measurement sites within Paris and concluded that the majority of the OOA emissions were linked to regional emissions rather than local emissions. Similar findings were reported during the REPARTEE (Harrison et al., 2012) and the EM25 (McMeeking et al., 2012) experiments in London. However, the increase of $\triangle \mathrm{OA} / \triangle \mathrm{CO}$ with photochemical age measured aboard the ATR-42, as well as results during MILAGRO, demonstrates that it is necessary to take into account a larger geographical area when assessing the formation of SOA from urban emissions.

The magnitude of the increase $\triangle \mathrm{OA} / \triangle \mathrm{CO}$ as a function of photochemical age measured during MEGAPOLI is similar for flights exposed to air masses with different source regions and compares well with equivalent measurements from other studies in London, Mexico City and in New England, USA. These results confirm previous observations of Kleinman et al. (2008), stating that aerosol yields remain similar regardless of the level of pollution.

Simultaneous AMS, $\mathrm{NO}_{\mathrm{x}} / \mathrm{NO}_{\mathrm{y}}$ and $\mathrm{VOC}$ measurements were available during two research flights. By using major anthropogenic SOA precursors (C6-C9 aromatics) and their corresponding organic aerosol formation yields reported for low $\mathrm{NO}_{\mathrm{x}}$ conditions, we were able to predict $\sim 50 \%$ of the organic aerosol measured in the plume. This value is consistent with studies using a similar approach in urban environments, including Paris (de Gouw et al., 2005; Aït-Helal et al., 2014). However, since a significant fraction of SOA remains unexplained, predicting its formation remains a challenge for future research. 


\section{Supplementary material related to this article is available online at http://www.atmos-chem-phys.net/14/ 1397/2014/acp-14-1397-2014-supplement.pdf.}

Acknowledgements. We would like to thank all the pilots and flight crew from SAFIRE for their help and enthusiasm. We gratefully acknowledge the European Union's Seventh Framework Programme FP/2007-2011 within the project MEGAPOLI (grant agreement no. 212520) for supporting the field experiments. E. Freney would also like to acknowledge the AXA research fund (ACI-AMS) and the Marie Curie reintegration grant (grant agreement no. 276728) for postdoctoral research funds.

Edited by: A. Baklanov

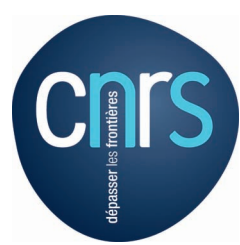

The publication of this article is financed by CNRS-INSU.

\section{References}

Ait-Helal, W., Borbon, A., Sauvage, S., de Gouw, J. A., Colomb, A., Beekmann, M., Afif, C., Durand-Jolibois, R., Fronval, I., Grand, N., Leonardis, T., Michoud, V., Miet, K., Perrier, S., Siour, G., Zapft, P., Doussin, J.-F., Lopez, M., Gros, V., Freutel, F., Schneider, J., Crippa, M., Prévôt, A. S. H., Baltensperger, U., and Locoge, N.: I/VOC in sub-urban Paris: variability, origin and importance in SOA formation, Atmos. Chem. Phys. Discuss., submitted, 2014.

Allan, J. D., Delia, A. E., Coe, H., Bower, K. N., Alfarra, M. R., Jimenez, J. L., Middlebrook, A. M., Drewnick, F., Onasch, T. B., Canagaratna, M. R., Jayne, J. T., and Worsnop, D. R.: A generalised method for the extraction of chemically resolved mass spectra from aerodyne aerosol mass spectrometer data, J. Aerosol Sci., 35, 909-922, 2004.

Atkinson, R. and Arey, J.: Atmospheric degradation of volatile organic compounds, Chem. Rev., 103, 4605-4638, 2003.

Bahreini, R., Dunlea, E. J., Matthew, B. M., Simons, C., Docherty, K. S., Carlo, P. F., Jimenez, J. L., Brock, C. A., and Middlebrook, A. M.: Design and operation of a pressure-controlled inlet for airborne sampling with an aerodynamic aerosol lens, Aerosol Sci. Technol., 42, 465-471, doi:10.1080/02786820802178514, 2008.

Bahrieni, R., Middlebrook, A. M., de Gouw, J. A., Warneke, C., Trainer, M., Brock, C. A., Stark, H., Brown, S. S., Dube, W. P., Gilman, J. B., Hall, K., Holloway, J. S., Kuster, W. C., Perring, A. E., Prevot, A. S. H., Schwarz, J. P., Spackman, J. R., Szidat, S., Wagner, N. L., Weber, R. J., Zotter, P., and Parrish, D. D.: Gasoline emissions dominate over diesel in formation of secondary organic aerosols mass, Geophys Res. Lett., 39, L06805, doi:10.1029/2011GL050718, 2012.

Baklanov, A., Lawrence, M., Pandis, S., Mahura, A., Finardi, S., Moussiopoulos, N., Beekmann, M., Laj, P., Gomes, L., Jaffrezo, J.-L., Borbon, A., Coll, I., Gros, V., Sciare, J., Kukko- nen, J., Galmarini, S., Giorgi, F., Grimmond, S., Esau, I., Stohl, A., Denby, B., Wagner, T., Butler, T., Baltensperger, U., Builtjes, P., van den Hout, D., van der Gon, H. D., Collins, B., Schluenzen, H., Kulmala, M., Zilitinkevich, S., Sokhi, R., Friedrich, R., Theloke, J., Kummer, U., Jalkinen, L., Halenka, T., Wiedensholer, A., Pyle, J., and Rossow, W. B.: MEGAPOLI: concept of multi-scale modelling of megacity impact on air quality and climate, Adv. Sci. Res., 4, 115-120, doi:10.5194/asr-4115-2010, 2010.

Berndt, T., Stratmann, F., Bräsel, S., Heintzenberg, J., Laaksonen, A., and Kulmala, M.: $\mathrm{SO}_{2}$ oxidation products other than $\mathrm{H}_{2} \mathrm{SO}_{4}$ as a trigger of new particle formation. Part 1: Laboratory investigations, Atmos. Chem. Phys., 8, 6365-6374, doi:10.5194/acp-86365-2008, 2008.

Borbon, A., Gilman, J. B., Kuster, W. C., Grand, N., Chevaillier, S., Colomb, A., Dolgorouky, C., Gros, V., Lopez, M., Sarda-Esteve, R., Holloway, J., Stutz, J., Perrussel, O., Petetin, H., McKeen, S., Beekmann, M., Warneke, C., Parrishand, D. D., and de Gouw, J. A.: Emission ratios of anthropogenic VOC in northern midlatitude megacities: observations vs. emission inventories in Los Angeles and Paris, J. Geophys. Res., 118, 2041-2057, 2013.

Bond, C. M., Anderson, T. L., Campbell, D., and Bond, T. C.: Calibration and intercomparison of filter-based measurements of visible light absorption by aerosols, Aerosol Sci. Technol., 30, 582 600, 1999.

Canagaratna, M. R., Jayne, J. T., Jimenez, J. L., Allan, J. D., Alfarra, M. R., Zhang, Q., Onasch, T. B., Drewnick, F., Coe, H., Middlebrook, A., Delia, A., Williams, L. R., Trimborn, A. M., Northway, M. J., DeCarlo, P. F., Kolb, C. E., Davidovits, P., and Worsnop, D. R.: Chemical and microphysical characterization of ambient aerosols with the aerodyne aerosol mass spectrometer, Mass Spectrom. Rev., 26, 185-222, 2007.

Canonaco, F., Crippa, M., Slowik, J. G., Baltensperger, U., and Prévôt, A. S. H.: SoFi, an IGOR-based interface for the efficient use of the generalized multilinear engine (ME-2) for the source apportionment: ME-2 application to aerosol mass spectrometer data, Atmos. Meas. Tech., 6, 3649-3661, doi:10.5194/amt6-3649-2013, 2013.

Chirico, R., DeCarlo, P. F., Heringa, M. F., Tritscher, T., Richter, R., Prévôt, A. S. H., Dommen, J., Weingartner, E., Wehrle, G., Gysel, M., Laborde, M., and Baltensperger, U.: Impact of aftertreatment devices on primary emissions and secondary organic aerosol formation potential from in-use diesel vehicles: results from smog chamber experiments, Atmos. Chem. Phys., 10, 11545-11563, doi:10.5194/acp-10-11545-2010, 2010.

Crippa, M., DeCarlo, P. F., Slowik, J. G., Mohr, C., Heringa, M. F., Chirico, R., Poulain, L., Freutel, F., Sciare, J., Cozic, J., Di Marco, C. F., Elsasser, M., Nicolas, J. B., Marchand, N., Abidi, E., Wiedensohler, A., Drewnick, F., Schneider, J., Borrmann, S., Nemitz, E., Zimmermann, R., Jaffrezo, J.-L., Prévôt, A. S. H., and Baltensperger, U.: Wintertime aerosol chemical composition and source apportionment of the organic fraction in the metropolitan area of Paris, Atmos. Chem. Phys., 13, 961-981, doi:10.5194/acp-13-961-2013, 2013a.

Crippa, M., El Haddad, I., Slowik, J. G., DeCarlo, P. F., Mohr, C., Heringa, M. F., Chirico, R., Marchand, N., Sciare, J., Baltensperger, U., and Prévôt, A. S. H.: Identification of marine and continental aerosol sources in Paris using high resolution 
aerosol mass spectrometry, J. Geophys. Res.-Atmos., 118, 1-19, doi:10.1029/jgrd.50151, 2013b.

Crumeyrolle, S., Gomes, L., Tulet, P., Matsuki, A., Schwarzenboeck, A., and Crahan, K.: Increase of the aerosol hygroscopicity by cloud processing in a mesoscale convective system: a case study from the AMMA campaign, Atmos. Chem. Phys., 8, 6907-6924, doi:10.5194/acp-8-6907-2008, 2008.

de Gouw, J. and Jimenez, J. L.: Organic Aerosols in the Earth's Atmosphere, Environ. Sci. Technol., 43, 7614-7618, doi:10.1021/es9006004, 2009.

de Gouw, J. A., Middlebrook, A. M., Warneke, C., Goldan, P. D., Kuster, W. C., Roberts, J. M., Fehsenfeld, F. C., Worsnop, D. R., Canagaratna, M. R., Pszenny, A. A. P., Keene, W. C., Marchewka, M., Bertman, S. B., and Bates, T. S.: Budget of organic carbon in a polluted atmosphere: Results from the New England Air Quality Study in 2002, J. Geophys. Res.-Atmos., 110, D16305, doi:10.1029/2004JD005623, 2005.

DeCarlo, P. F., Dunlea, E. J., Kimmel, J. R., Aiken, A. C., Sueper, D., Crounse, J., Wennberg, P. O., Emmons, L., Shinozuka, Y., Clarke, A., Zhou, J., Tomlinson, J., Collins, D. R., Knapp, D., Weinheimer, A. J., Montzka, D. D., Campos, T., and Jimenez, J. L.: Fast airborne aerosol size and chemistry measurements above Mexico City and Central Mexico during the MILAGRO campaign, Atmos. Chem. Phys., 8, 4027-4048, doi:10.5194/acp-84027-2008, 2008.

DeCarlo, P. F., Ulbrich, I. M., Crounse, J., de Foy, B., Dunlea, E. J., Aiken, A. C., Knapp, D., Weinheimer, A. J., Campos, T., Wennberg, P. O., and Jimenez, J. L.: Investigation of the sources and processing of organic aerosol over the Central Mexican Plateau from aircraft measurements during MILAGRO, Atmos. Chem. Phys., 10, 5257-5280, doi:10.5194/acp-10-52572010, 2010.

Deguillaume, L., Beekmann, M., and Derognat, C.: Uncertainty evaluation of ozone production and its sensitivity to emission changes over the Ile-de-France region during summer periods, J. Geophys. Res.-Atmos., 113, D02304, doi:10.1029/2007JD009081, 2008.

Docherty, K. S., Aiken, A. C., Huffman, J. A., Ulbrich, I. M., DeCarlo, P. F., Sueper, D., Worsnop, D. R., Snyder, D. C., Peltier, R. E., Weber, R. J., Grover, B. D., Eatough, D. J., Williams, B. J., Goldstein, A. H., Ziemann, P. J., and Jimenez, J. L.: The 2005 Study of Organic Aerosols at Riverside (SOAR-1): instrumental intercomparisons and fine particle composition, Atmos. Chem. Phys., 11, 12387-12420, doi:10.5194/acp-11-12387-2011, 2011.

Draxler, R. R. and Hess, G. D.: An overview of the HYSPLIT_4 modeling system of trajectories, dispersion, and deposition, Aust. Meteor. Mag., 47, 295-308, 1998.

Draxler, R. R. and Rolph, G. D.: HYSPLIT (HYbrid Single-Particle Lagrangian Integrated Trajectory) Model access via NOAA ARL READY Website (http://ready.arl.noaa.gov/HYSPLIT. php), NOAA Air Resources Laboratory, Silver Spring, MD, 2013.

Drewnick, F., Hings, S. S., DeCarlo, P. F., Jayne, J. T., Gonin, M., Fuhrer, K., Weimer, S., Jimenez, J. L., Demerjian, K. L., Borrmann, S., and Worsnop, D. R.: A new Time-of-Flight Aerosol Mass Spectrometer (ToF-AMS) - Instrument Description and First Field Deployment, Aerosol Sci. Technol., 39, 637-658 2005.
Freney, E. J., Sellegri, K., Canonaco, F., Boulon, J., Hervo, M., Weigel, R., Pichon, J. M., Colomb, A., Prévôt, A. S. H., and Laj, P.: Seasonal variations in aerosol particle composition at the puy-de-Dôme research station in France, Atmos. Chem. Phys., 11, 13047-13059, doi:10.5194/acp-11-13047-2011, 2011.

Freutel, F., Schneider, J., Drewnick, F., von der Weiden-Reinmüller, S.-L., Crippa, M., Prévôt, A. S. H., Baltensperger, U., Poulain, L., Wiedensohler, A., Sciare, J., Sarda-Estève, R., Burkhart, J. F., Eckhardt, S., Stohl, A., Gros, V., Colomb, A., Michoud, V., Doussin, J. F., Borbon, A., Haeffelin, M., Morille, Y., Beekmann, M., and Borrmann, S.: Aerosol particle measurements at three stationary sites in the megacity of Paris during summer 2009: meteorology and air mass origin dominate aerosol particle composition and size distribution, Atmos. Chem. Phys., 13, 933-959, doi:10.5194/acp-13-933-2013, 2013.

Harrison, R. M., Dall'Osto, M., Beddows, D. C. S., Thorpe, A. J., Bloss, W. J., Allan, J. D., Coe, H., Dorsey, J. R., Gallagher, M., Martin, C., Whitehead, J., Williams, P. I., Jones, R. L., Langridge, J. M., Benton, A. K., Ball, S. M., Langford, B., Hewitt, C. N., Davison, B., Martin, D., Petersson, K. F., Henshaw, S. J., White, I. R., Shallcross, D. E., Barlow, J. F., Dunbar, T., Davies, F., Nemitz, E., Phillips, G. J., Helfter, C., Di Marco, C. F., and Smith, S.: Atmospheric chemistry and physics in the atmosphere of a developed megacity (London): an overview of the REPARTEE experiment and its conclusions, Atmos. Chem. Phys., 12, 3065-3114, doi:10.5194/acp-12-3065-2012, 2012.

Healy, R. M., Sciare, J., Poulain, L., Kamili, K., Merkel, M., Müller, T., Wiedensohler, A., Eckhardt, S., Stohl, A., Sarda-Estève, R., McGillicuddy, E., O'Connor, I. P., Sodeau, J. R., and Wenger, J. C.: Sources and mixing state of size-resolved elemental carbon particles in a European megacity: Paris, Atmos. Chem. Phys., 12, 1681-1700, doi:10.5194/acp-12-1681-2012, 2012.

Hildebrandt, L., Engelhart, G. J., Mohr, C., Kostenidou, E., Lanz, V. A., Bougiatioti, A., DeCarlo, P. F., Prevot, A. S. H., Baltensperger, U., Mihalopoulos, N., Donahue, N. M., and Pandis, S. N.: Aged organic aerosol in the Eastern Mediterranean: the Finokalia Aerosol Measurement Experiment - 2008, Atmos. Chem. Phys., 10, 4167-4186, doi:10.5194/acp-10-4167-2010, 2010.

Hodzic, A., Vautard, R., Bessagnet, B., Lattuati, M., and Moreto, F.: Long-term urban aerosol simulation versus routine particulate matter observations, Atmos. Environ., 39, 5851-5864, 2005.

Hodzic, A., Jimenez, J. L., Madronich, S., Canagaratna, M. R., DeCarlo, P. F., Kleinman, L., and Fast, J.: Modeling organic aerosols in a megacity: potential contribution of semi-volatile and intermediate volatility primary organic compounds to secondary organic aerosol formation, Atmos. Chem. Phys., 10, 5491-5514, doi:10.5194/acp-10-5491-2010, 2010.

Kleinman, L. I., Daum, P. H., Lee, Y. N., Senum, G. I., Springston, S. R., Wang, J., Berkowitz, C., Hubbe, J., Zaveri, R. A., Brechtel, F. J., Jayne, J. T., Onasch, T. B., and Worsnop, D. R.: Aircraft observations of aerosol composition and ageing in New England and Mid?Atlantic States during the summer 2002 New England Air Quality Study field campaign, J. Geophys. Res., 112, D09310, doi:10.1029/2006JD007786m, 2007.

Kleinman, L. I., Springston, S. R., Daum, P. H., Lee, Y.-N., Nunnermacker, L. J., Senum, G. I., Wang, J., Weinstein-Lloyd, J., Alexander, M. L., Hubbe, J., Ortega, J., Canagaratna, M. R., and Jayne, J.: The time evolution of aerosol composition over 
the Mexico City plateau, Atmos. Chem. Phys., 8, 1559-1575, doi:10.5194/acp-8-1559-2008, 2008.

Kleinman, L. I., Springston, S. R., Wang, J., Daum, P. H., Lee, Y.-N., Nunnermacker, L. J., Senum, G. I., Weinstein-Lloyd, J., Alexander, M. L., Hubbe, J., Ortega, J., Zaveri, R. A., Canagaratna, M. R., and Jayne, J.: The time evolution of aerosol size distribution over the Mexico City plateau, Atmos. Chem. Phys., 9, 4261-4278, doi:10.5194/acp-9-4261-2009, 2009.

Lanz, V. A., Alfarra, M. R., Baltensperger, U., Buchmann, B., Hueglin, C., and Prévôt, A. S. H.: Source apportionment of submicron organic aerosols at an urban site by factor analytical modelling of aerosol mass spectra, Atmos. Chem. Phys., 7, 15031522, doi:10.5194/acp-7-1503-2007, 2007.

Liu, P., Deng, R., Smith, K. A., Williams, L. R., Jayne, J. T., Canagaratna, M. R., Moore, K., Onash, T. B., Worsnop, D. R., and Deshler, T.: Transmission efficiency of an Aerodynamic Focusing Lens system: Comparison of model calculations and laboratory measurements for the Aerodyne Aerosol mass spectrometer, Aerosol Sci. Technol., 8, 721-733, doi:10.1080/02786820701422278, 2007.

McFarland, A. R., Gong, H., Muyshondt, A., Wente, W. B., and Anand, N. K.: Aerosol deposition in bends with turbulent flow, Environ. Sci. Technol., 12, 3371-3377, doi:10.1021/es960975c, 1997.

McMeeking, G. R., Bart, M., Chazette, P., Haywood, J. M., Hopkins, J. R., McQuaid, J. B., Morgan, W. T., Raut, J.-C., Ryder, C. L., Savage, N., Turnbull, K., and Coe, H.: Airborne measurements of trace gases and aerosols over the London metropolitan region, Atmos. Chem. Phys., 12, 5163-5187, doi:10.5194/acp12-5163-2012, 2012.

Middlebrook, A. M., Bahreini, R., Jimenez, J. L., and Canagaratna, M. R.: Evaluation of Composition-Dependent Collection Efficiencies for the Aerodyne Aerosol Mass Spectrometer using Field Data, Aerosol Sci. Technol., 46, 258-271, doi:10.1080/02786826.2011.620041, 2012.

Nedelec, P., Cammas, J.-P., Thouret, V., Athier, G., Cousin, J.-M., Legrand, C., Abonnel, C., Lecoeur, F., Cayez, G., and Marizy, C.: An improved infrared carbon monoxide analyser for routine measurements aboard commercial Airbus aircraft: technical validation and first scientific results of the MOZAIC III programme, Atmos. Chem. Phys., 3, 1551-1564, doi:10.5194/acp-3-15512003, 2003

Ng, N. L., Kroll, J. H., Chan, A. W. H., Chhabra, P. S., Flagan, R. C., and Seinfeld, J. H.: Secondary organic aerosol formation from m-xylene, toluene, and benzene, Atmos. Chem. Phys., 7, 3909-3922, doi:10.5194/acp-7-3909-2007, 2007.

Ng, N. L., Canagaratna, M. R., Zhang, Q., Jimenez, J. L., Tian, J., Ulbrich, I. M., Kroll, J. H., Docherty, K. S., Chhabra, P. S., Bahreini, R., Murphy, S. M., Seinfeld, J. H., Hildebrandt, L., Donahue, N. M., DeCarlo, P. F., Lanz, V. A., Prévôt, A. S. H., Dinar, E., Rudich, Y., and Worsnop, D. R.: Organic aerosol components observed in Northern Hemispheric datasets from Aerosol Mass Spectrometry, Atmos. Chem. Phys., 10, 46254641, doi:10.5194/acp-10-4625-2010, 2010.

Ng, N. L., Canagaratna, M. R., Jimenez, J. L., Zhang, Q., Ulbrich, I. M., and Worsnop, D. R.: Real-Time Methods for Estimating Organic Component Mass Concentrations from Aerosol Mass Spectrometer Data, Environ. Sci. Technol., 45, 910-916, doi:10.1021/es102951k, 2011.
Paatero, P.: Least squares formulation of robust non-negative factor analysis, Chemometr. Intell. Lab., 37, 23-35, 1997.

Paatero, P. and Tapper, U.: Positive matrix factorization - a nonnegative factor model with optimal utilization of error-estimates of data values, Environmetrics, 5, 111-126, 1994.

Park, R. J., Jacob, D. J., Palmer, P. I., Clarke A. D., Weber R. J., Zondlo, M. A., Eisele, F. L., Brandy, A. R., Thornton, D. C, Sachse, G. W., and Bond, T. C.: Export efficiency of black carbon aerosol in continental outflow: Global implications, J. Geophys. Res.-Atmos., 110, D11205, doi:10.1029/2004JD005432, 2005.

Platt, S. M., El Haddad, I., Zardini, A. A., Clairotte, M., Astorga, C., Wolf, R., Slowik, J. G., Temime-Roussel, B., Marchand, N., Ježek, I., Drinovec, L., Mocnik, G., Möhler, O., Richter, R., Barmet, P., Bianchi, F., Baltensperger, U., and Prévôt, A. S. H.: Secondary organic aerosol formation from gasoline vehicle emissions in a new mobile environmental reaction chamber, Atmos. Chem. Phys., 13, 9141-9158, doi:10.5194/acp-13-91412013, 2013.

Sciare, J., d'Argouges, O., Zhang, Q. J., Sarda-Estève, R., Gaimoz, C., Gros, V., Beekmann, M., and Sanchez, O.: Comparison between simulated and observed chemical composition of fine aerosols in Paris (France) during springtime: contribution of regional versus continental emissions, Atmos. Chem. Phys., 10, 11987-12004, doi:10.5194/acp-10-11987-2010, 2010.

Sellegri, K., Laj, P., Peron, F., Dupuy, R., Legrand, M., Preunkert, S., Putaud, J.-P., Cachier, H., and Ghermandi, G.: Mass balance of free tropospheric aerosol at the Puy de Dôme (France) in winter, J. Geophys. Res., 108, 4333, doi:10.1029/2002JD002747, 2003.

Shilling, J. E., Zaveri, R. A., Fast, J. D., Kleinman, L., Alexander, M. L., Canagaratna, M. R., Fortner, E., Hubbe, J. M., Jayne, J. T., Sedlacek, A., Setyan, A., Springston, S., Worsnop, D. R., and Zhang, Q.: Enhanced SOA formation from mixed anthropogenic and biogenic emissions during the CARES campaign, Atmos. Chem. Phys., 13, 2091-2113, doi:10.5194/acp-13-20912013, 2013.

Spracklen, D. V., Jimenez, J. L., Carslaw, K. S., Worsnop, D. R., Evans, M. J., Mann, G. W., Zhang, Q., Canagaratna, M. R., Allan, J., Coe, H., McFiggans, G., Rap, A., and Forster, P.: Aerosol mass spectrometer constraint on the global secondary organic aerosol budget, Atmos. Chem. Phys., 11, 12109-12136, doi:10.5194/acp-11-12109-2011, 2011.

Song, J., Lei, W., Bei, N., Zavala, M., de Foy, B., Volkamer, R., Cardenas, B., Zheng, J., Zhang, R., and Molina, L. T.: Ozone response to emission changes: a modeling study during the MCMA-2006/MILAGRO Campaign, Atmos. Chem. Phys., 10, 3827-3846, doi:10.5194/acp-10-3827-2010, 2010

Sullivan, A. P., Peltier, R. E., Brock, C. A., de Gouw, J. A., Holloway, J. S., Warneke, C., Wollny, A. G., and Weber, R. J.: Airborne measurements of carbonaceous aerosol soluble in water over northeastern United States: Method development and an investigation into water-soluble organic carbon sources, J. Geophys. Res., 111, D23S46, doi:10.1029/2006jd007072, 2006.

Ulbrich, I. M., Canagaratna, M. R., Zhang, Q., Worsnop, D. R., and Jimenez, J. L.: Interpretation of organic components from Positive Matrix Factorization of aerosol mass spectrometric data, Atmos. Chem. Phys., 9, 2891-2918, doi:10.5194/acp-9-2891-2009, 2009. 
Volkamer, R., Jimenez, J. L., San Martini, F., Dzepina, K., Zhang, Q., Salcedo, D., Molina, L. T., Worsnop, D. R., and Molina, M. J.: Secondary organic aerosol formation from anthropogenic air pollution: Rapid and higher than expected, Geophys Res. Lett., 33, L17811, doi:10.1029/2006GL026899, 2006.

Weber, R. J., Sullivan, A. P., Peltier, R. C., Russell, A., Yan, B., Zheng, M., de Gouw, J., Warnke, C., Brock, C., Holloway, J. S., Atlas, E. L., and Edgerton, E.: A study of secondary organic aerosol formation in the anthropogenicinfluenced southeastern United States, J. Geophys. Res., 112, D13302, doi:10.1029/2007JD008408, 2007.

Zhang, K. M. and Wexler, A. S.: Evolution of particle number distributions near roadways Part I: Analysis of aerosol dynamics and its implication for engine emissions measurement, Atmos. Environ., 38, 6643-6665, 2004.
Zhang, Q. J., Beekmann, M., Drewnick, F., Freutel, F., Schneider, J., Crippa, M., Prevot, A. S. H., Baltensperger, U., Poulain, L., Wiedensohler, A., Sciare, J., Gros, V., Borbon, A., Colomb, A., Michoud, V., Doussin, J.-F., Denier van der Gon, H. A. C., Haeffelin, M., Dupont, J.-C., Siour, G., Petetin, H., Bessagnet, B., Pandis, S. N., Hodzic, A., Sanchez, O., Honoré, C., and Perrussel, O.: Formation of organic aerosol in the Paris region during the MEGAPOLI summer campaign: evaluation of the volatilitybasis-set approach within the CHIMERE model, Atmos. Chem. Phys., 13, 5767-5790, doi:10.5194/acp-13-5767-2013, 2013. 